\title{
Biomarkers of Atherosclerosis and Acute Coronary Syndromes - A Clinical Perspective
}

\author{
Richard Body ${ }^{1}$, Mark Slevin ${ }^{2,3}$ and Garry McDowell ${ }^{4,5}$ \\ ${ }^{1}$ Cardiovascular Sciences Research Group, University of Manchester, Manchester, \\ ${ }^{2}$ School of Biology, Chemistry and Health Science, John Dalton Building, \\ Manchester Metropolitan University, Manchester, \\ ${ }^{3}$ Cardiovascular Research Centre, CSIC-ICCC, \\ Hospital de la Santa Creu i Sant Pau, Barcelona, \\ ${ }^{4}$ Faculty of Health, Edge Hill University, Ormskirk, \\ ${ }^{5}$ School of Translational Medicine, University of Manchester, Manchester, \\ $1,2,4,5$ UK \\ ${ }^{3}$ Spain
}

\section{Introduction}

Coronary heart disease remains the single biggest killer in the United Kingdom, accounting for around one in five deaths in men and one in six deaths in women (1). In 2003 the total annual cost of coronary heart disease in the United Kingdom was around $£ 3.5$ billion ( $£ 60$ per capita), with the cost of inpatient care accounting for around $79 \%$ of these costs (2). Approximately $3 \%$ of patients who attend the ED have chest pain that the treating physician suspects may be cardiac in origin (3). $74-88 \%$ of these patients are admitted to hospital, making up one in five of all medical admissions (3-5). Ultimately only a quarter of these patients will be diagnosed with an acute coronary syndrome (ACS), which implies that a very cautious approach to the problem has been adopted. Despite this fact, up to $6 \%$ of the patients with chest pain who are discharged from the ED actually have myocardial damage that has prognostic significance (6). These patients are up to three times as likely to die as similar patients who were admitted to hospital (7).

\section{The pathophysiology of coronary heart disease}

Over the past century tremendous advances have been made in our understanding of coronary heart disease and its pathophysiological evolution. In 1910 a Russian physician first described the clinical presentation of acute myocardial infarction (AMI) (8). Two years later, an association was drawn between AMI and acute thrombotic coronary occlusion (9). By 1913 it had been hypothesised that atherosclerosis developed as a result of gradual lipid accumulation within the arterial wall (10). The advent of coronary revascularisation procedures in the latter half of the 20th century allowed the observation that restoring blood flow beyond significant coronary stenotic lesions often led to alleviation of anginal symptoms. This helped to propagate the widespread belief that the greater the coronary 
stenosis the greater the risk of a clinically significant event such as AMI or unstable angina pectoris. This axiom underpins much of modern practice in cardiology. Figure 1 illustrates the traditional model of the evolution of coronary atheroma (11).
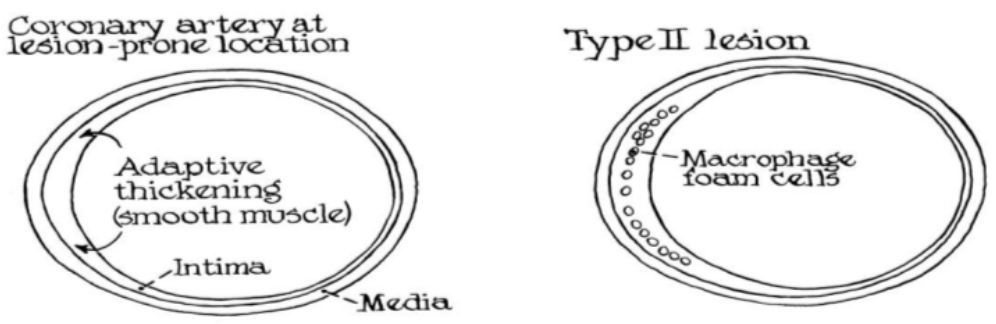

\section{Type III (preatheroma)}

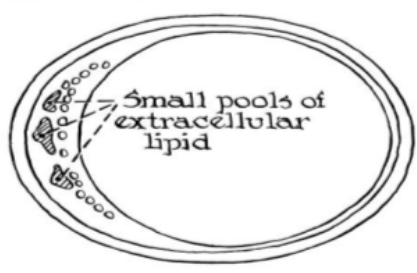

\section{Type Z (fibroatheroma)}

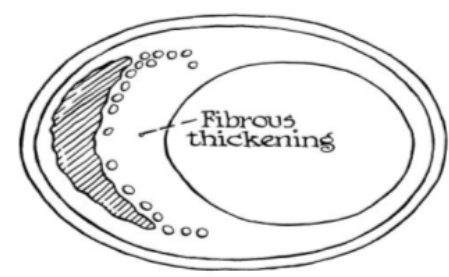

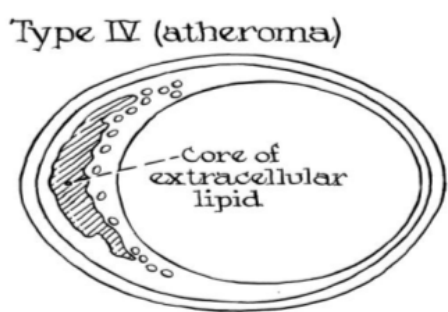

\section{Type VI (complicated lesion)}

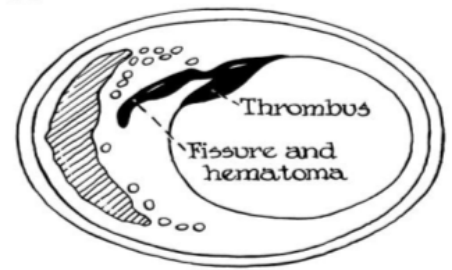

Fig. 1. Drawings of cross sections of the most proximal parts of six left anterior descending coronary arteries, illustrated to depict the traditional concept of the evolution of coronary atheroma. From Stary et al, 1995 (11).

In recent years this whole concept has been challenged. Far from a bland disease of cholesterol storage characterised by a passive accumulation of lipid within the vessel wall, a growing body of research and a progression in current thinking suggest that coronary atherosclerosis is in fact a dynamic inflammatory disease, dependent upon complex interactions between the immune, coagulation and humoral systems. It would seem that progression of coronary atherosclerosis is not so much a gradual process as a stepwise one, often characterised by swift and sudden increases in plaque size. Atherosclerotic plaque rupture or endothelial damage may lead to haemorrhage into the plaque or thrombus formation with subsequent organisation. This leads to rapid expansion of the plaque (12). Further, the severity of coronary stenosis on angiography does not predict the development of subsequent AMI (13). Indeed, two thirds of AMIs are provoked by plaques that cause less 
than $50 \%$ stenosis on angiography (14). The explanation for these phenomena resides in the understanding that there are, in basic terms, two kinds of coronary atheromatous plaques: those which are stable and those which are unstable. While stable plaques may be responsible for stable anginal symptoms (such as exertional chest pain relieved by rest), they are less likely to rupture and cause the clinical manifestations that we recognise as ACS. Meanwhile, unstable plaques are vulnerable and highly likely to rupture with the ensuing risk of developing ACS. There are notable pathological differences between these two types of plaque. Stable plaques are more likely to cause coronary stenosis, presenting a fixed obstruction to blood flow and therefore often being responsible for causing stable anginal symptoms such as exertional chest pain. Unstable plaques, however, may cause little arterial stenosis, thus explaining the observation that the majority of AMIs are caused by lesions that are only mildly stenotic. What is more, they may cause little in the way of clinical symptoms until they rupture, leading to the often dramatic and frequently fatal clinical manifestations of ACS.

Pathologically, stable plaques are likely to be more enriched with smooth muscle cells than those which are prone to rupture. They are likely to contain a dense fibrous cap consisting of collagen and extracellular matrix, which give the plaque tensile strength. On the contrary, plaques that are vulnerable to rupture are likely to have thin, friable fibrous caps, contain abundant inflammatory cells including macrophages and they are rich in extracellular lipid, often with a lipid core containing pro-inflammatory oxygen free radicals, pro-thrombotic material such as tissue factor and necrotic cellular debris (Figure 2) $(15 ; 16)$.

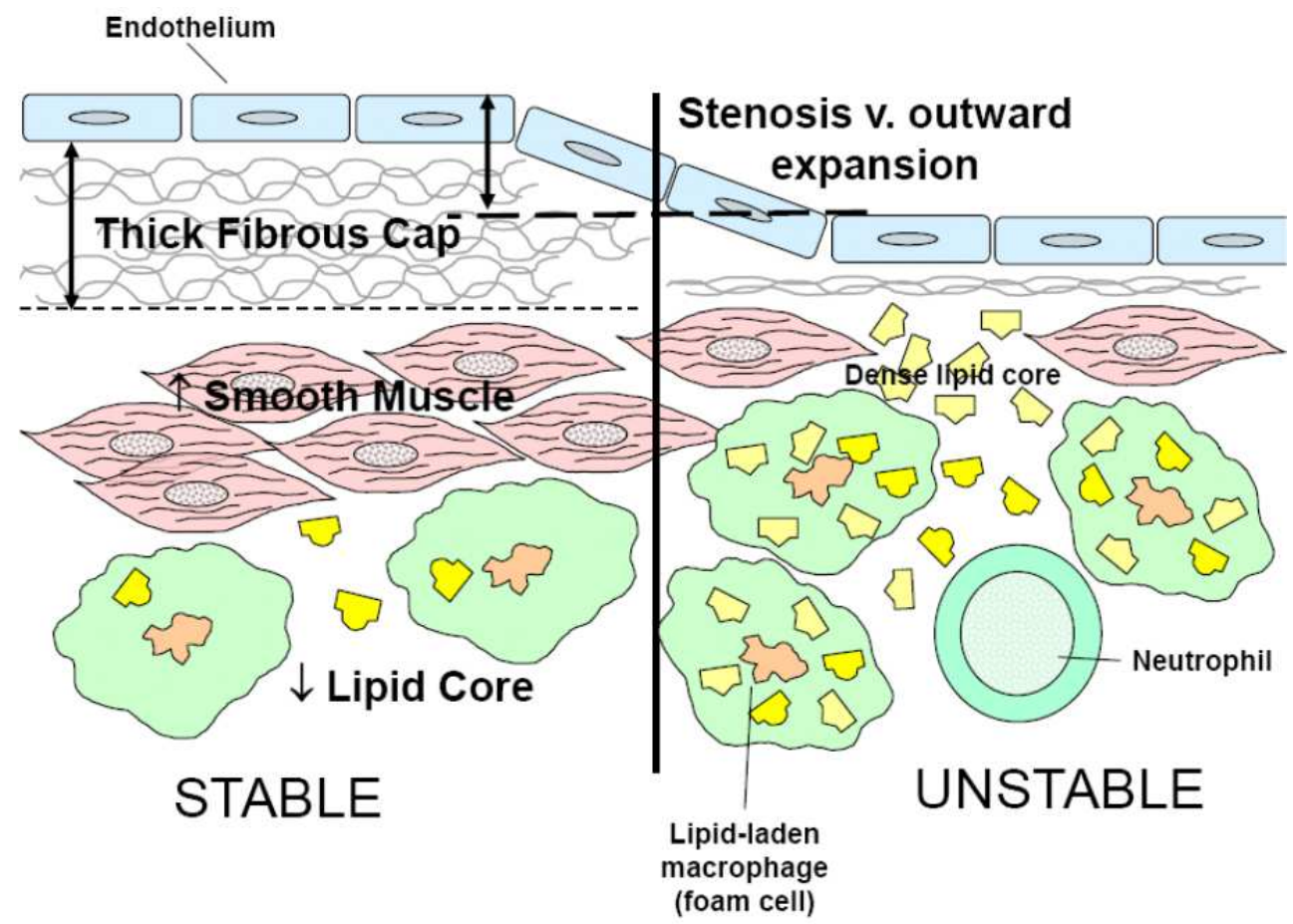

Fig. 2. Stability and instability: The two varieties of coronary atheroma. 
While an unstable plaque often causes little or no arterial stenosis, it does not follow that unstable plaques are necessarily smaller in size than their stable counterparts. It has become apparent that the arterial wall is not a static and rigid structure but rather is capable of socalled 'outward remodelling', increasing its external diameter without narrowing the lumen. An unstable plaque may therefore be comparatively large in size while causing little arterial stenosis $(15 ; 17-21)$.

\subsection{The pathophysiological evolution of an acute coronary syndrome}

In order to fully comprehend the limitations to current diagnostic strategies and to attempt the development of effective new strategies for the diagnosis of ACS it is important to have a reasonable understanding of the initiation and progression of the disease from a molecular level upwards. If we can recognise the precise disease processes we are trying to accurately identify, we stand a much better chance of understanding our current problems and of developing effective novel diagnostic strategies that can be applied in clinical practice.

Coronary atherosclerosis is an inflammatory disease whose origins can only be adequately understood through a sound appreciation of vascular biology (17;22-27). We no longer regard the blood vessel wall as simply an inert tubular conduit for flowing blood but rather as a complex living structure that plays a pivotal role in maintaining vascular homeostasis and integrity. Of particular importance in this regard is the endothelium, a monolayer of cells forming a barrier between flowing blood and tissue. The human endothelium has a total surface area of approximately $1000 \mathrm{~m}^{2}(16)$ and constitutes around $16 \%$ of the myocardium (28). It plays a key role in modulating vascular tone, responding to neural, humoral and mechanical stimuli by synthesising and releasing vasoactive substances. By sending activating signals to circulating inflammatory cells, the endothelium orchestrates complex fluid and cellular movements designed to neutralise and eliminate foreign elements. While these mechanisms are usually beneficial, under certain circumstances these processes can become extreme and counter-productive $(29 ; 30)$.

The endothelium is an active player in the protection against and development of coronary disease, being the guardian of the integrity of the vessel wall. A functional endothelium produces a healthy balance of vascular constricting and relaxing factors. In this respect, the role of endothelium-derived nitric oxide is particularly crucial. In addition to its important vasodilator effect, nitric oxide protects against vascular injury, inflammation and thrombosis. It inhibits leukocyte adhesion to the endothelium, smooth muscle cell proliferation and migration and platelet aggregation (31-34). In the presence of traditional cardiac risk factors such as hyperlipidaemia, smoking, diabetes and hypertension and where there is local or systemic inflammation or reduced shear stress (such as at the branch points of coronary arteries), nitric oxide production is inhibited and its degradation enhanced (Figure 3) (23). Under these conditions, many of the protective inhibitory effects of nitric oxide are lost. Cell adhesion molecules (CAMs) including P-selectin and E-selectin are expressed by the endothelium, where they mediate leukocyte binding. P-selectin and Eselectin bind to carbohydrates that are constitutively expressed on the surface of circulating leukocytes, causing the leukocytes to bind loosely to the endothelial surface and to literally roll across it, scanning the endothelium for further activating signals. Chemoattractant cytokines or chemokines that are also expressed by activated endothelial cells can then induce a conformational change in integrin molecules expressed at the leukocyte cell 
surface, changing them from a low-affinity to a high-affinity state (35). These activated integrins may then bind firmly to two further adhesion molecules that are expressed by activated endothelium: intercellular adhesion molecule-1 (ICAM-1) and vascular cellular adhesion molecule-1 (VCAM-1). This strong adhesion brings the rolling leukocytes to a halt.

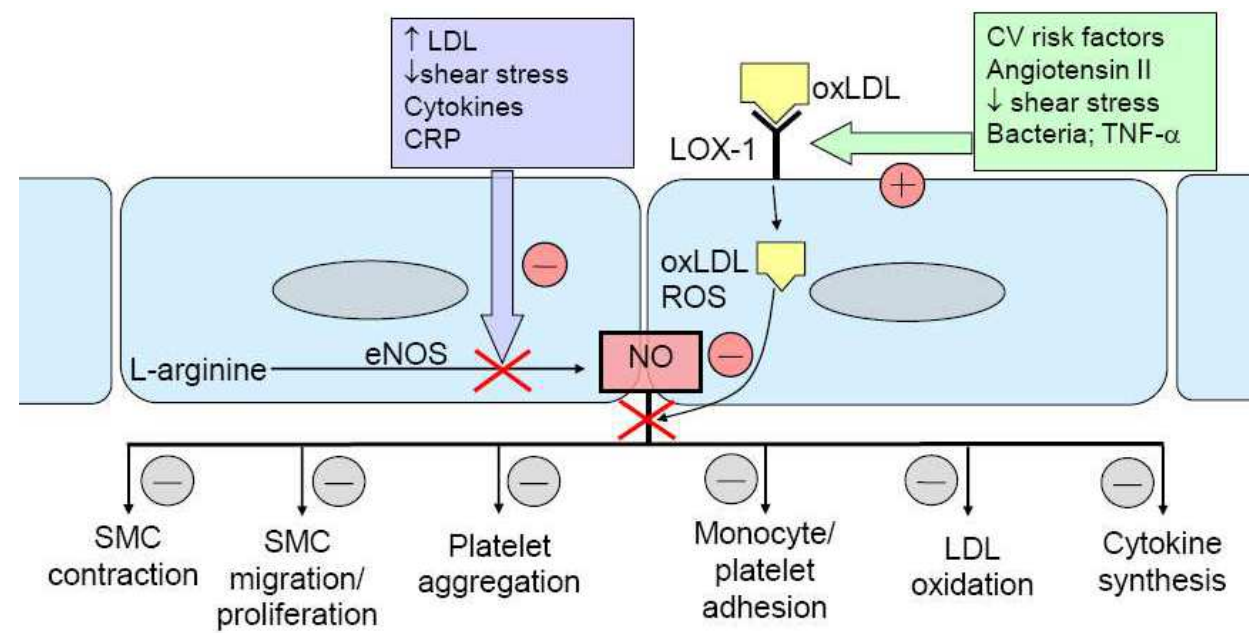

Fig. 3. The pivotal anti-atherogenic role of nitric oxide on a molecular level. Abbreviations: LDL, low density lipoprotein; CRP, C-reactive protein; $C V$, cardiovascular; TNF- $\alpha$, tumour necrosis factor a; oxLDL, oxidised LDL; ROS, reactive oxygen species; SMC, smooth muscle cell; NO, nitric oxide; LOX-1, oxidised LDL receptor-1; eNOS, endothelial nitric oxide synthase.

In the presence of further activating signals from within the arterial intima, the leukocytes may subsequently undergo a cytoskeletal change, enabling them to squeeze between the tight cell-cell junctions of the endothelium via interactions with the PECAM-1 (CD31) receptor. Again, under normal circumstances PECAM-1 binds endothelial cells strongly together, preventing leukocyte migration into the arterial intima. However, substances such as thrombin and histamine that are expressed during periods of localised inflammation loosen this binding, promoting cellular retraction and vascular permeability. This enables glycoproteins on the cell surface of the activated leukocytes to bind to PECAM-1, allowing them to pass through the endothelial layer into the arterial intima in a process labelled diapedesis $(29 ; 36)$. Within the arterial intima, activated leukocytes will then migrate towards chemokines (including monocyte chemotactic protein, MCP-1) expressed within foci of inflammation where they participate in inflammatory processes (Figure 4$)(29 ; 37 ; 38)$.

Circulating low-density lipoprotein (LDL) cholesterol can also bind to endothelial receptors and is subsequently modified or oxidised by the endothelial cells. Within the arterial intima, oxidised LDL acts as a strong stimulus for further migration and localisation of inflammatory cells (16). Following migration, monocytes mature into macrophages and, via scavenger receptors, ingest oxidised LDL to become foam cells (24). Together with $\mathrm{T}$ lymphocytes and activated endothelial cells, these cells secrete an array of pro-inflammatory cytokines, forming a positive feedback loop which enhances the inflammatory reaction within the arterial intima. If the inflammatory stimuli are not removed or neutralised, this process will continue indefinitely (27). 


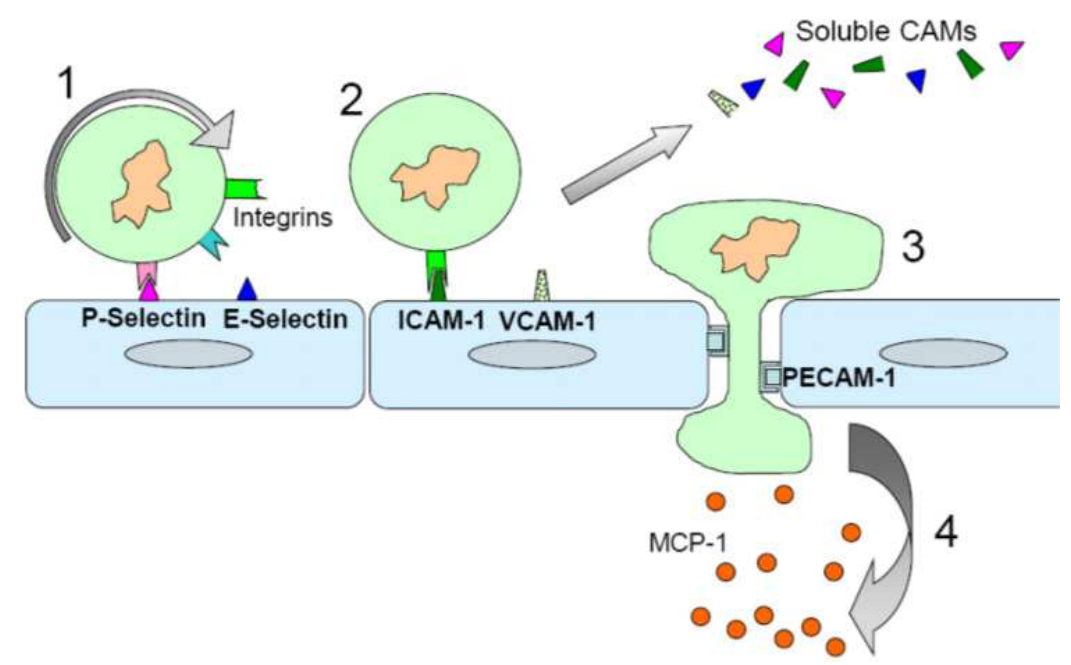

Fig. 4. The multistep model of leukocyte migration. 1. Leukocytes bind to selectins expressed by activated endothelium, causing them to roll, scanning the endothelium for activating signals. 2. In the presence of activating signals, integrins on the cell surface of the leukocyte undergo a structural change and can bind firmly to ICAM-1 and VCAM-1. 3. Leukocytes can then migrate through to the arterial intima by binding to PECAM-1 at the cell junction. 4. Leukocytes migrate along a chemokine gradient (illustrated as MCP-1), which helps to localise the inflammatory response within the intima. Cell adhesion molecules are subsequently released into the circulation in soluble form.

In addition to enhancing inflammation, cytokines stimulate differentiation and migration of smooth muscle cells from the arterial media into the intima (39). While this may ultimately lead to mechanical expansion of the plaque, smooth muscle cells actually play a vital role in maintaining the stability of the atherosclerotic plaque by secreting a dense, fibrous extracellular matrix and substances that prevent its degradation (tissue inhibitors of metalloproteinases, TIMPs) (16) (Figure 5).

Enhanced inflammatory activity within the plaque ultimately renders the plaque vulnerable to rupture by destabilising this fibrous cap. Activated macrophages and neutrophils within atheroma secrete myeloperoxidase (MPO), an enzyme which enhances consumption of nitric oxide, generating highly reactive and pro-inflammatory oxygen free radicals and oxidised LDL, thus perpetuating and enhancing both endothelial dysfunction and the formation of foam cells $(40 ; 41)$. MPO inactivates TIMPs, paving the way for degradation of the fibrous cap. Further, MPO activates matrix metalloproteinases (MMPs), enzymes responsible for actively degrading the fibrous cap (42) (Figure 6) (43).

Atheroma is rendered even more vulnerable to rupture by interactions between the CD40 receptor (which is expressed by endothelial cells, monocytes and B lymphocytes) and its ligand CD40L, which is expressed by activated $\mathrm{T}$ helper cells, smooth muscle cells, macrophages, basophils and activated platelets $(44 ; 45)$. This interaction leads to the formation of another positive feedback loop that enhances endothelial dysfunction and inflammation within the plaque and stimulates the release of both the procoagulant tissue factor and MMPs into the lipid core (46-50). The latter further enhance degradation of the fibrous cap (Figure 6). 


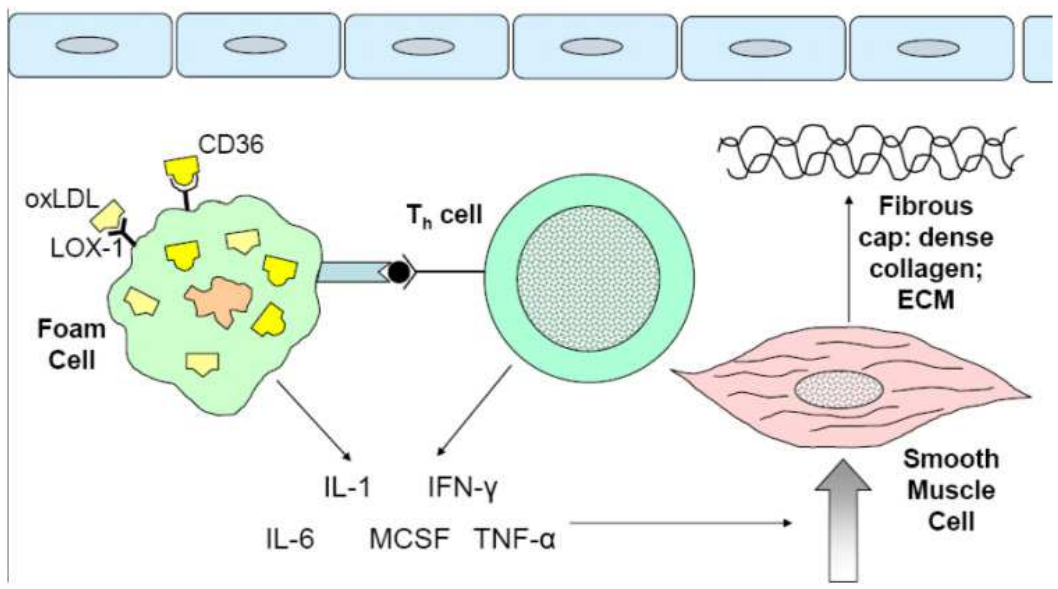

Fig. 5. Progression to organised atheroma. Following migration into the arterial intima, monocytes mature into tissue macrophages and, via receptors including LOX-1 and CD36, take up extracellular lipid including oxidised LDL cholesterol (oxLDL) to become foam cells. Together with T helper cells (Th), foam cells secrete an array of pro-inflammatory cytokines (interleukin-1 (IL-1), interferon- $\gamma$ (IFN- $\gamma$ ), interleukin-6 (IL-6), monocyte colony stimulating factor (MCSF), tumour necrosis factor- $\alpha$ (TNF- $\alpha)$ ), which lead to migration of vascular smooth muscle cells from the arterial media. Following migration, these smooth muscle cells secrete a dense extracellular matrix (ECM) and collagen fibres, which form a tough fibrous cap.

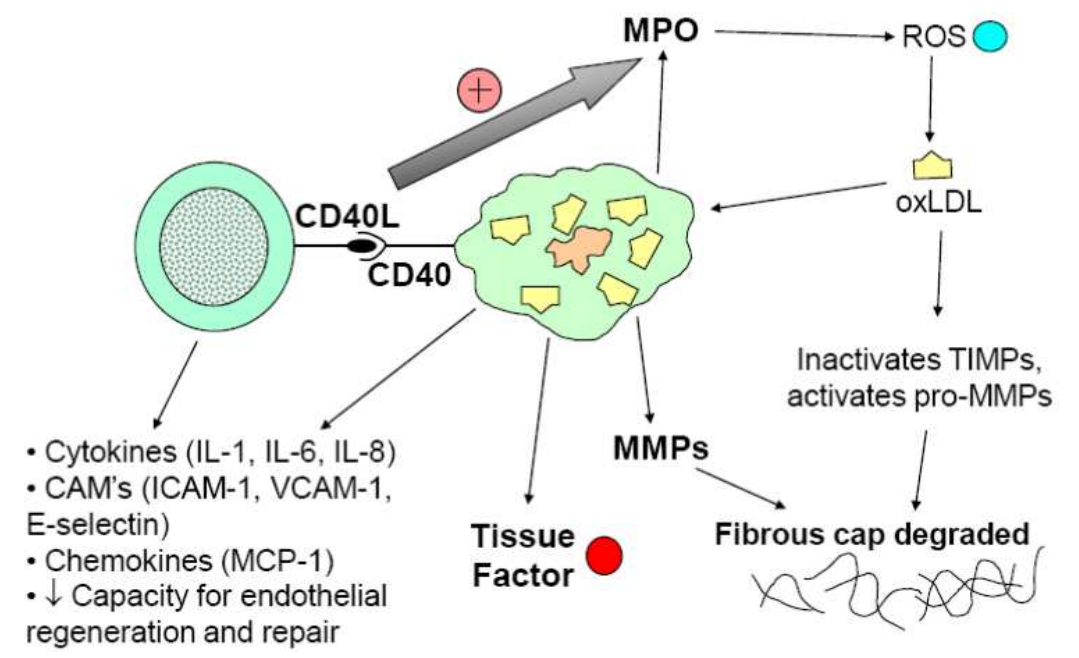

Fig. 6. CD40/L interactions within coronary atheroma. CD40/40L interactions lead to enhanced inflammation, impaired capacity for endothelial repair and regeneration, secretion of pro-coagulant tissue factor, MMPs and upregulation of myeloperoxidase (MPO) secretion. MPO produces reactive oxygen species (ROS) and oxidised LDL (oxLDL), enhancing upregulation and leading to degradation of the fibrous cap by activating the precursors of MMPs (pro-MMPS) and inhibiting tissue inhibitors of metalloproteinases (TIMPs). 
Where there is abundant intimal inflammation, pro-inflammatory cytokines may prime cells within the plaque for apoptotic death upon engagement with activated $\mathrm{T}$ lymphocytes $(22 ; 51)$. Stimulated apoptosis of smooth muscle cells impedes maintenance of the fibrous cap, favouring its breakdown. Apoptosis of endothelial cells may lead to erosions of the endothelial layer, enabling circulating blood to come into contact with the pro-thrombotic contents of the plaque (Figure 7). Circulating platelets are activated upon contact, binding to the arterial wall and to each other (52). When these areas of endothelial erosion are small, this platelet aggregation occurs only on a microscopic level and is clinically insignificant, serving only to stimulate endothelial regeneration and smooth muscle growth. The new endothelial cells may be dysfunctional, however, predisposing to vasoconstriction (15).

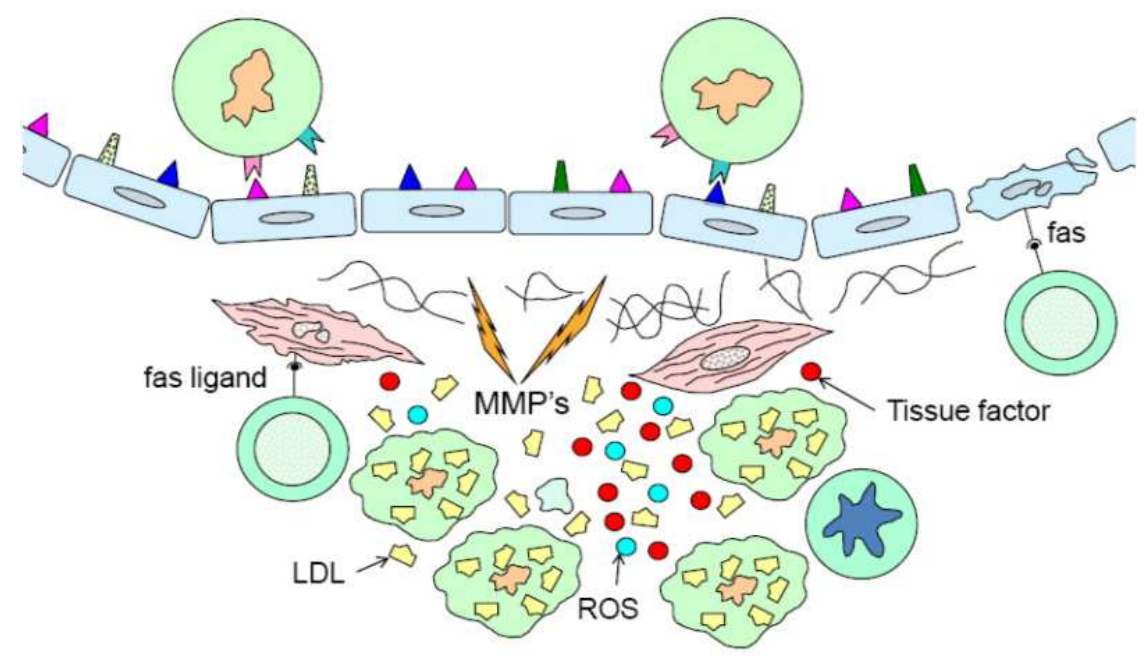

Fig. 7. Positive feedback loops within unstable coronary atheroma and processes leading to endothelial erosion.

In the presence of larger endothelial erosions there may be a rapid increase in intimal inflammation (53) and sufficient platelet aggregation and subsequent fibrin deposition to produce a large thrombus with symptomatic luminal obstruction $(15 ; 17 ; 54 ; 55)$. In itself, this process accounts for approximately $25 \%$ of all major thrombi that lead to acute coronary syndromes (56) and may have even greater importance in women and young people (57). Of even greater importance, however, is the high tensile stress that a vulnerable plaque must withstand. As the lipid core is soft and deformable, it cannot bear circumferential stress. This stress is therefore borne by the fibrous cap, made of tough collagen and extracellular matrix. Depending upon the shape of the plaque and its position within the artery, the fibrous cap must withstand focal concentrations of load up to seven or eight times normal systolic wall stress $(58 ; 59)$. This is particularly significant in unstable plaques where the fibrous cap may be thin and friable.

Ultimately, this may lead to sudden rupture of the plaque with endothelial disruption, causing haemorrhage of circulating blood into the core of the plaque (Figure 8). This may be particularly likely to occur following a trigger such as unaccustomed physical activity or emotional stress, which leads to a rapid increase in systolic blood pressure and thus increased circumferential stress on an already vulnerable plaque (60). 


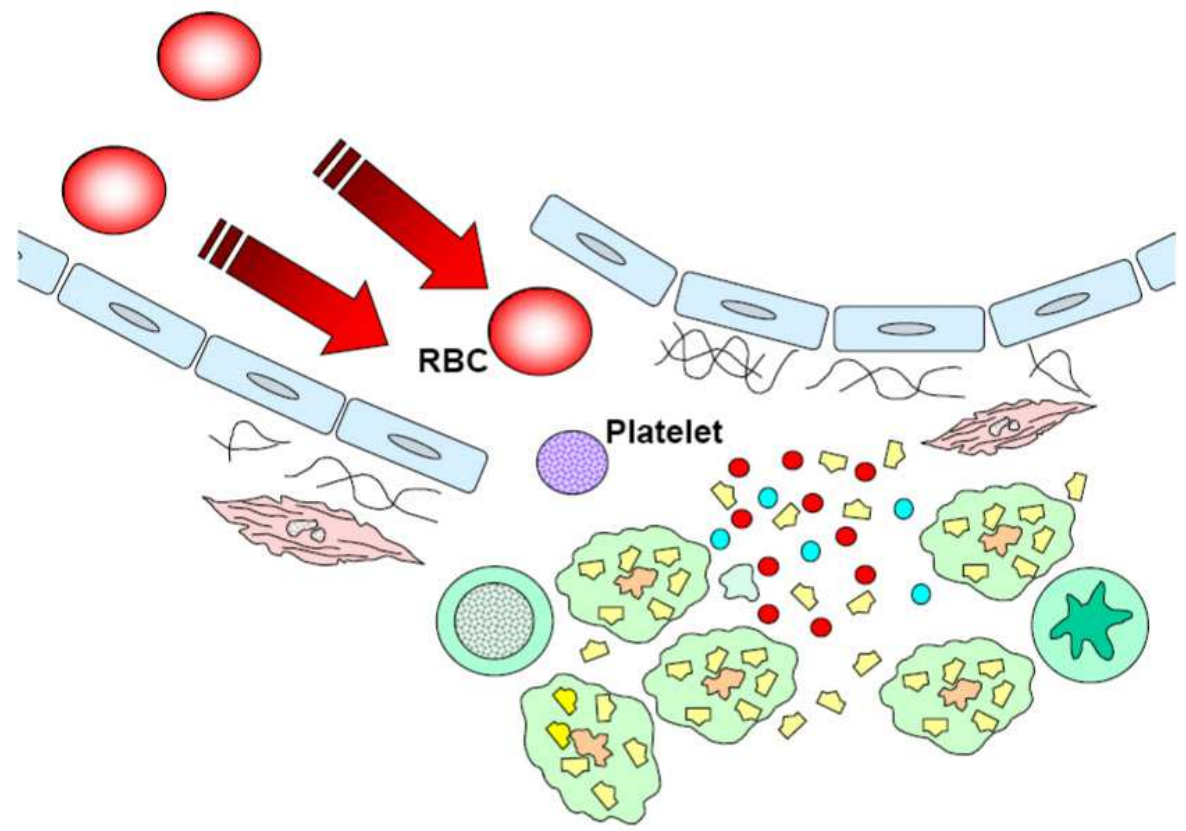

Fig. 8. Plaque rupture. There is haemorrhage into the plaque, causing rapid expansion and, as the contents of the lipid core are highly prothrombotic, thrombus formation ensues. Abbreviations: RBC, red blood cell.

Circulating blood is exposed to the prothrombotic lipid core. Tissue factor activates factor VIIa, which ultimately leads to the cleavage of thrombin from prothrombin and further activation of the coagulation cascade (61). Several substances from within the plaque, including thrombin, CD40L and P-selectin, activate circulating platelets by inducing a conformational change in the glycoprotein receptors and enabling cross-linking or adhesion via fibrinogen and other adhesive ligands. During this process, activated platelets themselves express P-selectin and CD40L, which appear to be necessary for the formation of a stable arterial thrombus (62-64). Both P-selectin and CD40L are later enzymatically cleaved from the platelet surface and released into the circulation in soluble form $(65 ; 66)$.

When plaque rupture is small, intraplaque haemorrhage may lead to rapid expansion with platelet activation and adhesion but the thrombus does not extend into the arterial lumen (12). The thrombus subsequently undergoes organisation, the endothelial layer regenerates and the episode is clinically silent. Among patients with coronary atheroma who died of non-vascular causes such as motor vehicle accidents and subsequently underwent postmortem examination, up to $8 \%$ were noted to have had a recent plaque disruption with intra-plaque thrombi (67). Indeed, in pathological studies of subjects who died of ischaemic heart disease each patient had on average two to three plaque disruptions, although in each case one culprit thrombus was identified that was apparently responsible for causing death (68-70). In the presence of a large plaque rupture or, indeed, when the rupture is not large but the patient is in a pro-thrombotic state (for example during periods of stress or systemic 
infection), platelet activation and aggregation may extend into the arterial lumen. Activation of the coagulation cascade leads to fibrin deposition, which increases the size of the thrombus. Again, thrombus formation may be arrested without causing significant luminal stenosis. However, as the thrombus is exposed to flowing blood distal emboli may occur, potentially causing myocardial necrosis on a microscopic level and recognisable symptoms. As activated platelets aggregate to form a platelet-rich arterial thrombus, they release mediators such as serotonin and thromboxane A2, which cause vasoconstriction. This may lead to localised coronary arterial spasm, which even in the absence of an obstructive coronary thrombus, may lead to transmural myocardial ischaemia and a clinically apparent ACS (71). When thrombus formation continues unchecked, total arterial occlusion may occur. If such occlusion occurs suddenly in a previously uncompromised artery without a well-developed collateral circulation, significant downstream myocardial necrosis will occur with the clinically recognisable signs of acute myocardial infarction (AMI). The cell membranes of the necrosed myocytes are breached and their intracellular constituents are washed out into the circulation. These constituents include myoglobin, creatine kinase, the cardiac troponins and human fatty acid binding protein.

\section{Biomarkers of unstable coronary disease}

Current diagnostic strategies incorporate biomarkers of myocardial necrosis, the end-point in the pathophysiological evolution of ACS. The measurement of cardiac troponins in the bloodstream has revolutionised the diagnosis of AMI in this regard, enabling the detection of microscopic amounts of myocardial necrosis that could not have previously been identified (72). As described in detail earlier in this chapter, however, a whole host of pathophysiological processes have occurred before myocardial necrosis, none of which are detectable using current diagnostic technology. In fact myocardial necrosis is merely a surrogate marker of the disease process, which occurs within the coronary artery and not the cardiac myocyte. As it is possible to use biomarkers to detect myocardial necrosis with high sensitivity and specificity this raises the additional possibility that other biomarkers may be able to detect evidence of the disease process itself within the coronary arteries. A number of novel biomarkers have been investigated in this regard in recent years.

\subsection{Soluble cell adhesion molecules}

Cell adhesion molecules (CAMs) mediate the interactions between the endothelium and blood cells, enabling the localised inflammatory response that is essential for the initiation and propagation of coronary atherosclerosis. Their upregulation enhances this inflammatory response, which ultimately renders the atherosclerotic plaque vulnerable to rupture. Following their expression, CAMs are shed from the cell surface. As these soluble CAMs are detectable in peripheral blood, they are promising candidates for use as early markers of vascular activation (37). CAMs that have attracted interest as potential biomarkers of ACS include the molecules P-selectin, E-selectin, ICAM-1 and VCAM-1.

\subsubsection{P-selectin}

P-selectin mediates the interaction of platelets and endothelial cells with neutrophils and monocytes (65). It is expressed by endothelial cells in atherosclerotic, but not normal, vessels 
$(73,74)$, with expression being particularly marked in patients with unstable angina (75). Pselectin is also expressed by activated platelets and has been used as a marker of platelet activation (76). Several investigators have demonstrated significantly raised soluble Pselectin levels in patients with AMI (77-84), unstable angina (85-88) and cohorts of patients with any ACS $(89,90)$. However conflicting results have also been reported, with two reports that P-selectin does not help to predict adverse events in patients with ACS and two studies that did not detect any elevation of plasma P-selectin levels in patients with ACS compared with controls (91-93).

Five studies have investigated the utility of P-selectin for diagnosis of ACS in the ED population. One small study of 44 patients found no different in plasma soluble P-selectin levels between patients diagnosed with ACS and non-cardiac pain (94). Although the same group also reported that P-selectin was not an independent predictor for a diagnosis of ACS (95), another group reported that P-selectin was an independent predictor for the occurrence of serious cardiac events within three months of presentation to the ED with chest pain (96). Other groups have reported sensitivities of 35 and $55.8 \%$ and NPVs of 53 and $71 \%$ for the diagnosis of ACS (97-98). The data suggests that the use of soluble P-selectin as a sole ruleout strategy for ACS in the ED is likely to lead to an unacceptably high false negative rate. Our own data however in 713 patients presenting to the ED with suspected cardiac chest pain demonstrated P-selectin had early diagnostic value for AMI and prognostic significance independent of troponin T and ECG findings (99)

\subsubsection{E-selectin}

E-selectin has also been investigated in this regard. Plasma levels of E-selectin have been shown to correlate with the severity of coronary atherosclerosis $(87,100)$. A number of studies have reported elevated plasma E-selectin levels in patients with AMI (101-108). Eselectin elevations have also been reported in patients with unstable angina $(85,109)$. Other studies have reported raised E-selectin in all ACS (80,82,110-112). Plasma E-selectin levels in patients with AMI may be higher among patients who experienced a prodrome of unstable angina (105). Raised E-selectin levels have also been reported following attacks of variant angina (113), although there may be no difference in E-selectin levels during episodes of stable angina (114). A reduction in plasma E-selectin levels has been described in patients with AMI following successful reperfusion $(101,108)$. Further, plasma E-selectin levels may be useful for predicting the risk of death among patients with AMI (103). However not all reports have been consistent. Three groups have failed to find elevated E-selectin levels in ACS (115-117). There is no clear explanation for the discrepancy in the results, although one group measured E-selectin in serum rather than plasma, which may have introduced an important bias. Only one study has investigated E-selectin levels in the ED population with undifferentiated chest pain (118). This study failed to demonstrate a difference in E-selectin levels between patients with AMI, unstable angina and controls. However, the study had significant limitations, including small numbers, suboptimal gold standards and no clinical follow-up. The study was not designed to appraise the performance of E-selectin as a diagnostic test for use in the ED. The available research suggests that E-selectin has promising characteristics for use as a marker of ACS. A large prospective observational cohort study is necessary to evaluate its performance as a diagnostic test. Incorporation into 
a multimarker strategy with markers that may reflect other aspects of the pathophysiological evolution of ACS may be necessary to obtain sufficient sensitivity.

\subsubsection{Intercellular Adhesion Molecule-1 (ICAM-1) and Vascular Cell Adhesion Molecule-1 (VCAM-1)}

ICAM-1 and VCAM-1 are responsible for mediating firm adhesion of leukocytes to the endothelium, enabling their subsequent migration. ICAM-1 (but not VCAM-1) levels have been shown to predict adverse cardiac events in apparently healthy men (119-121) and women (122) and may help to predict the development $(121,123)$ and progression of coronary atherosclerosis (124). In addition, ICAM-1 (but not VCAM-1) levels are raised in patients with stable angina and levels may correlate with disease severity (125-127). Levels of both VCAM-1 and ICAM-1 have been shown to be elevated in patients with ACS (128129), although conflicting results have also been reported (130). Interestingly, levels of VCAM-1 and ICAM-1 in patients with unstable angina who had demonstrable ruptured plaque on coronary intravascular ultrasound were significantly higher than in patients with stable angina who had no evidence of plaque rupture, although neither biomarker was an independent predictor of plaque rupture on multivariate analysis (131). Finally, VCAM-1 and ICAM-1 levels have both been shown to predict prognosis and complications in patients with confirmed ACS (91,103,128,132-137). Evidence for the use of ICAM-1 and VCAM-1 in the ED population with undifferentiated chest pain is disappointing, however. A study of 241 men who presented to the ED with chest pain failed to find a significant difference in ICAM-1 and VCAM-1 levels between patients with AMI and patients with (presumed) noncardiac chest pain, although the gold standards for diagnosis of non-cardiac pain were suboptimal (138). Other studies have demonstrated no correlation between ICAM-1 and VCAM-1 levels and the occurrence of adverse events within three months of presentation $(96,139)$. One study demonstrated that ICAM-1 predicted in-hospital adverse events with a sensitivity of $63.3 \%$, a specificity of $47.2 \%$ and a NPV of $79.3 \%$, which is clearly not sufficient for ICAM-1 to be used in the clinical environment (140).

\subsubsection{Soluble CD40 Ligand (sCD40L)}

As described earlier in this chapter sCD40L plays a pivotal role in mediating interactions between inflammatory cells within coronary atheroma that ultimately render the plaque vulnerable to rupture. In addition, sCD40L is expressed by activated platelets and plasma levels have been shown to correlate with platelet activation (141). Case control studies have consistently demonstrated elevated levels of sCD40L in patients with ACS when compared with controls (48;141-151). sCD40L levels have also been shown to stratify patients with confirmed ACS according to their risk of developing adverse events (152), although conflicting results have also been reported $(153,154)$. An analysis of data from 1088 patients with confirmed ACS who had been enrolled in a randomised controlled trial (the c7E3 Fab antiplatelet therapy in unstable refractory angina (CAPTURE) trial) and 626 patients who were admitted to hospital with acute chest pain, found that SCD40L was a powerful independent predictor of adverse events at 72 hours, 30 days and six months. Levels correlated poorly with troponin $\mathrm{T}$ and may thus identify a separate at-risk group. However sCD40L may be more useful for prognostication than diagnosis. Using the 97.5th percentile 
upper reference limit as a diagnostic cut-off sCD40L had a sensitivity of only $56.5 \%$ for the diagnosis of ACS in the patients with acute chest pain (141).

\subsection{Myeloperoxidase (MPO)}

MPO is an enzyme secreted by phagocytic cells. It utilises hydrogen peroxidise to generate oxygen free radicals. In health this leads to the generation of hypochlorous acid, which has bactericidal and viricidal properties (155). Neutrophils and foam cells within coronary atheroma also produce MPO, where the generation of highly reactive oxygen free radicals leads to the generation of oxidised LDL cholesterol, which enhances the formation of foam cells propagating inflammation (156). It also perpetuates the endothelial dysfunction by enhancing the breakdown of nitric oxide (155). Further, MPO activates MMPs from their precursors and inactivates their physiological inhibitors, TIMPS (42). This enables breakdown of the fibrous cap, rendering the plaque vulnerable to rupture. MPO is abundantly expressed by macrophages in eroded or ruptured coronary plaques, although it has not been identified in fatty streaks (43). While expression is enhanced in unstable angina and AMI, it is not enhanced in variant angina or in response to ischaemia in chronic stable angina (157). These findings suggest that increased MPO expression is associated with the ongoing inflammatory process rather than indicating reperfusion injury or a tissue response to ischaemia. Blood levels of MPO have been shown to correlate strongly with the presence of coronary artery disease. When divided into quartiles, patients with MPO levels in the fourth quartile had an adjusted odds ratio for the presence of coronary artery disease of 20.4 compared to patients in the first quartile. MPO levels were more predictive of risk of coronary artery disease than Framingham risk score (158).

A case control study involving 874 patients demonstrated elevated MPO levels in patients with ACS compared with controls who had normal coronary angiograms (159). Two separate analyses of data from randomised controlled trials, involving a total of 2,614 patients, have reported that MPO levels help to predict the occurrence of adverse events in patients with confirmed ACS. Interestingly MPO was found to add additional prognostic information to cardiac troponins. However the rate of major adverse events within 30 days in patients with MPO levels below selected cut-offs remained around 5\% in both studies $(160,161)$. Other studies have also demonstrated that MPO levels in patients with confirmed ACS help to predict prognosis (162-165) , although one study reported that MPO levels did not help to predict mortality among 325 male patients who had been admitted to hospital with chest pain and were awaiting coronary angiography (166). Several studies have investigated the use of MPO in the ED population. The largest study, of 604 consecutive patients presenting to the ED with suspected cardiac chest pain, found that MPO levels predicted a diagnosis of ACS with sensitivity $65.7 \%$, specificity $60.7 \%$, PPV $53.3 \%$, and NPV $72.2 \%$. MPO levels also predicted adverse events, although $14.8 \%$ of patients with normal MPO and troponin levels still had a major adverse event within 30 days (167). A second study of 414 low risk patients who presented to the ED with suspected ACS found that MPO had a sensitivity of $71 \%$, specificity $32 \%$ and negative likelihood ratio 0.89 (95\% CI 0.26 2.05), suggesting that MPO was not a useful diagnostic test for AMI. However the study was underpowered as only seven patients were diagnosed with ACS (168). Among 140 consecutive ED patients with chest pain, MPO helped to diagnose AMI with sensitivity 92.3\% (CI 95\% 66.7\% - 99.6\%), specificity 40.2\% (CI 95\% 32.0\% - 48.9\%), PPV 13.6\% (CI 95\% 
8.0\% - 22.3\%) and NPV 98.1\% (CI 95\% 89.9\% - 99.9\%). Again, however, the study was underpowered, with only 13 patients being diagnosed with AMI (169). Finally, MPO levels measured in 148 ED patients with chest pain were found to be significantly higher among those diagnosed with AMI. However MPO was both insensitive $(13.9 \%$ of patients with MPO levels in the bottom quartile had AMI) and non-specific as a diagnostic marker for AMI (only $38.4 \%$ of patients with values in the highest quartile had AMI). MPO levels were found to be significant predictors of adverse events within 30 days (167) The available data suggest that MPO is unlikely to have sufficient sensitivity or specificity to be useful as an early diagnostic marker of ACS in the ED. However it may have a role for risk stratification and prediction of prognosis, particularly in troponin negative patients.

\subsection{Pregnancy-Associated Plasma Protein A (PAPP-A)}

PAPP-A is a matrix metalloproteinase (MMP), one of a family of at least 25 proteases, of which 14 have been characterised in vascular cells. They are secreted by a variety of cells that are involved in the atherosclerotic process including foam cells, endothelial cells, $\mathrm{T}$ lymphocytes, mast cells and smooth muscle cells (170). They are upregulated in atherosclerotic plaque and play a pivotal role in the degradation of the fibrous cap that renders the plaque vulnerable to rupture $(171,172)$. PAPP-A was originally detected in the serum in late pregnancy and has been used in first trimester screening for Down's syndrome (173). It is also abundantly expressed in unstable but not stable atherosclerotic plaques (54) and raised levels have been shown to correlate with complex coronary stenoses on angiography (174). A small case control study involving a total of 69 patients found that PAPP-A levels were significantly higher in patients with AMI or unstable angina compared to patients with stable angina and healthy controls without coronary disease (54). PAPP-A has been investigated as a potential early marker of AMI, with mixed results. A study of 346 patients who presented to the ED with chest pain found that PAPP-A levels were significantly higher in those patients who were diagnosed with AMI (175). In a second study that included 415 patients admitted to a cardiology unit with suspected ACS, PAPP-A levels were also found to be significantly higher in those patients with AMI although the AUC was only 0.56, suggesting that PAPP-A is unlikely to be useful as a lone diagnostic investigation for AMI (176). Further, a case control study found no significant difference in PAPP-A levels between 80 patients with STEMI and 80 healthy controls (177). Finally, among 59 patients who presented to the ED with suspected ACS and were deemed to be at intermediate risk for having a significant coronary event, PAPP-A was found to be an independent predictor of a diagnosis of ACS (odds ratio 2.09), following adjustment for other clinical factors (178).

When tested at the time of presentation in the ED population, PAPP-A may help to predict cardiac events in the near future. In a subgroup of a large study involving 626 ED patients with chest pain, Heeschen et al found that PAPP-A predicted adverse events with an adjusted odds ratio of 2.32 (179). In an ED population of 136 patients with suspected ACS but negative troponin I, Lund et al found PAPP-A to be an independent predictor of adverse cardiac events at six months, albeit with a sensitivity of only $54 \%$, specificity $75 \%$, PPV $30 \%$ and NPV 15\% (180). In a study of 364 ED patients with suspected ACS, Laterza et al reported that PAPP-A predicted adverse events at 30 days with a sensitivity of $66.7 \%$, specificity $51.5 \%$, PPV $12.6 \%$ and NPV 93.6\%. Thus for every 100 patients discharged and reassured on the basis of a negative PAPP-A level, three would have an adverse cardiac 
events within 30 days (175). Finally, among 422 patients who presented to the ED with chest pain but had neither troponin elevations nor ECG abnormalities, PAPP-A was found to be a significant predictor of adverse events after a median of 60 weeks follow up, although this was not significant once other factors had been taken into account (including a clinical risk score, exercise tolerance testing and plasma levels of other biomarkers) (181). The available evidence suggests that PAPP-A levels alone are unlikely to be sufficient to enable early diagnosis of AMI in the ED or to accurately identify a population of patients who are at sufficiently low risk of adverse events to affect clinical practice.

\subsection{Coagulation markers}

\subsubsection{D-dimer}

D-dimer is a degradation product of cross-linked fibrin. Its presence indicates both thrombus formation and subsequent endogenous fibrinolysis, thus confirming that both thrombin and plasmin have been generated (182). It is a sensitive tool for exclusion of venous thromboembolism in the low risk group (183). In ACS plaque rupture or erosion is followed by exposure of the procoagulant lipid core to circulating blood with ensuing thrombus formation. As coronary thrombus precedes myocardial necrosis, it is possible that coagulation markers such as D-dimer are sensitive markers of ACS, potentially rising earlier than markers of myocardial necrosis including troponins. Elevated D-dimer levels in apparently healthy males have been shown to predict the future occurrence of AMI, ACS and coronary heart disease $(121,184,185)$. Further, patients in whom the first presentation of coronary heart disease is with AMI may have higher D-dimer levels than patients who first present with stable angina (186). A weak but statistically significant correlation has been demonstrated between plasma D-dimer levels and severity of coronary disease on angiography in patients with unstable angina $(187,188)$. In a cohort of 54 patients who were diagnosed with unstable angina and underwent coronary angiography, D-dimer levels (cutoff $270 \mathrm{ng} / \mathrm{ml}$ ) predicted significant coronary disease on angiography with sensitivity $70 \%$, specificity 50\%, PPV $86 \%$, NPV 72\%. By lowering the cut-off to $200 \mathrm{ng} / \mathrm{ml}$ sensitivity increased to $95 \%$ but specificity dropped to $20 \%$ (189).

Several studies have demonstrated that patients with ACS have elevated levels of D-dimer when compared to controls with stable angina or no coronary disease $(139,190,193)$. Plasma D-dimer level has also been shown to be a significant predictor of long-term mortality (after a median of 29 months follow up) in 320 patients with a diagnosis of NSTE-ACS (194), although a separate study of 358 patients with NSTE-ACS found that D-dimer did not predict the occurrence of adverse events (death, AMI, revascularisation or hospital admission for acute heart failure) within six months (hazard ratio 1.26, 95\% CI $0.79-2.02$ ) (195). Among 257 patients D-dimer levels (cut-off 500ng/l) at the time of admission (mean 160 minutes from symptom onset) diagnosed AMI with sensitivity $65 \%$, specificity $80 \%$, PPV 36\% and NPV 93\%, although the study utilised an outdated gold standard (incorporating CK-MB levels) for the diagnosis of AMI. D-dimer levels were found to be significantly higher in patients who were diagnosed with ischaemic pain, AMI and unstable angina (196). Another study of 184 patients who presented to the ED with suspected cardiac chest pain showed that D-dimer levels taken at the time of presentation were on average $111 \%$ higher in patients who were diagnosed with ACS compared to those who were not. Ddimer (at a cut-off of $1 \mathrm{mg} / \mathrm{l}$ ) had a sensitivity of $18 \%$ in order to achieve a set specificity of 
$92 \%$, although the implications of accepted a more conventional, lower D-dimer cut-off were not evaluated (197). In 102 patients who presented to a Brazilian ED, D-dimer levels at the time of ED presentation were significantly higher in patients who had a troponin $\mathrm{T}$ $>0.01 \mathrm{ng} / \mathrm{ml}$ at the time of presentation compared with patients whose troponin $\mathrm{T}$ was $<0.01 \mathrm{ng} / \mathrm{ml}$. Unfortunately the results of 12-hour troponin testing were not available for analysis in this study, precluding evaluation of true diagnostic performance for AMI (198). The largest study to have investigated the use of D-dimer for the diagnosis of AMI in ED patients included a total of 741 patients who presented to the ED with suspected AMI. In that study, plasma D-dimer levels measured 12-24 hours after arrival at the ED had an AUC of 0.734 (95\% CI $0.715-0.753)$ for predicting a troponin T result of $>0.03 \mathrm{ng} / \mathrm{ml}$. At a cut-off of $500 \mu \mathrm{g} / 1 \mathrm{D}$-dimer had a sensitivity of $95 \%$, specificity $27 \%$, PPV $92 \%$ and NPV $41 \%$ (199). Finally, in a study of 432 patients who presented to the ED with suspected ACS D-dimer levels measured at the time of ED presentation did not help to predict the occurrence of adverse events (death, AMI, revascularisation, recurrent ACS or hospital admission with congestive heart failure) after 42 days of follow up (odds ratio 1.3, 95\% CI $0.4-4.5$, at a cutoff of $500 \mu \mathrm{g} / 1)$.

The evidence suggests that D-dimer is unlikely to be useful as an early marker of AMI when used alone in the ED population and at present the evidence for the use of D-dimer as a prognostic marker is also sparse. Future research into this biomarker must focus upon evaluating its potential value as part of a multimarker strategy.

\subsection{Markers of ventricular stress}

\subsubsection{Brain Natriuretic Peptide (BNP)}

BNP was first isolated from porcine brains but it has since been recognised as a cardiac hormone synthesised predominantly by the ventricles in response to ventricular wall stress. Together with atrial natriuretic peptide, which is secreted primarily by the atria, BNP belongs to the natriuretic peptide family that is involved in cardiac homeostasis. Biological effects include diuresis, vasodilatation, inhibition of the renin-aldosterone system and of cardiac and vascular myocyte growth (200). BNP is known to be a marker of acute and chronic left ventricular dysfunction and may be useful for the ED diagnosis of the former $(201,202)$. It has been used as a marker of left ventricular systolic dysfunction following AMI, where it provides prognostic information (203). BNP is also expressed in ischaemic human myocardium and plasma levels may rise during periods of ischaemia (204-208). A number of studies, that together have included a total of 5159 patients, have demonstrated that BNP level acts as a strong predictor of mortality at seven days, 30 days, six months and 10 months in patients with confirmed ACS (208-214). Other studies have shown that BNP levels help to predict all adverse cardiac events, both during the index hospital admission and at follow up after up to 1 year (215-217). BNP levels have also been shown to help predict the development of congestive heart failure when measured in patients with both STEMI and NSTE-ACS (218-219). In addition to having prognostic value, there is evidence that BNP may assist in the diagnosis of ACS. Several small case control studies have demonstrated higher BNP levels in patients with AMI (220-222) and unstable angina $(223,224)$ when compared with controls. There is some evidence to suggest that BNP levels may, in fact, correlate with infarct size (225). However, among 1676 patients with confirmed NSTE-ACS only $15.6 \%$ of patients had BNP levels above $80 \mathrm{pg} / \mathrm{ml}$. Indeed only $25.2 \%$ of 
patients with NSTEMI had BNP levels above $80 \mathrm{pg} / \mathrm{ml}$, suggesting that BNP, at least at the stated diagnostic cut-off, may have limited sensitivity for these diagnoses (211).

In a study of 100 patients who were admitted to a Medical Admissions Unit with suspected cardiac chest pain, BNP (diagnostic cut-off $5 \mathrm{pg} / \mathrm{ml}$ ) helped to diagnose AMI with sensitivity $88.6 \%$, specificity $78.6 \%$, PPV 75\%, NPV $89.6 \%$ with an AUC of 0.868 . BNP was significantly more sensitive but less specific than troponin $\mathrm{T}$ when used at the time of admission to the unit. By combining BNP and troponin $\mathrm{T}$ performance improved (sensitivity 95.4\%, specificity $76.8 \%$ ). Unfortunately, however, this study had significant weaknesses as the primary outcome (discharge diagnosis of cardiac pain) could not be objectively verified through use of a gold standard, the study was retrospective and no follow up data was provided (226). Several studies have investigated the diagnostic and prognostic value of BNP levels in the ED population. Among 631 consecutive patients who presented to the ED with suspected cardiac chest pain with symptom onset $<12$ hours, BNP levels at the time of admission were found to be significantly higher among patients who were ultimately diagnosed with AMI (227). For predicting a diagnosis of AMI, BNP had an AUC of 0.710 . Using a cut-off of $100 \mathrm{pg} / \mathrm{ml}$ BNP predicted AMI with sensitivity $70.8 \%$, specificity $68.9 \%$, PPV 22.7\%, NPV 94.8\%, positive likelihood ratio 2.28 and negative likelihood ratio 0.42 . When combined with CK-MB and troponin I, the presence of any raised biomarker for a diagnosis of AMI performed with sensitivity $87.3 \%$, specificity $65.7 \%$, PPV $27.0 \%$, NPV $97.3 \%$, positive likelihood ratio 2.55 and negative likelihood ratio 0.19 . This suggests that, had BNP been introduced into clinical practice, this would have enabled the early detection of an additional 22 AMIs that could not otherwise have been recognised at the time of admission. However this would come at a cost of 163 false positive diagnoses (227). In a retrospective analysis of 546 patients who presented to the ED with suspected cardiac chest pain, a point-of-care BNP test was found to have an AUC of 0.755 for a diagnosis of AMI. At a cut-off of $100 \mathrm{ng} / \mathrm{l}$, BNP sensitivity was $66.7 \%$, specificity $71.3 \%$, PPV $17.1 \%$, NPV 96.0\%, positive likelihood ratio 2.32 and negative likelihood ratio 0.47 . However the study had significant weaknesses. Clinicians were not blinded to BNP results, the study was subject to significant verification bias as only a minority of patients with normal point of care tests underwent subsequent gold standard troponin testing and, for those who did undergo troponin testing, an outdated troponin cut-off was used to diagnose AMI (228). Another study prospectively recruited 306 patients who presented to the ED with suspected cardiac chest pain. BNP was measured using two separate assays at the time of admission. The AUC of each assay for a diagnosis of ACS was found to be less than 0.6. BNP levels were found to be significant predictors of adverse events after 30 and 90 days but, again, the AUC was less than 0.7 for each assay (229).

Finally, in another prospective cohort study, 426 patients who presented to the ED with suspected cardiac chest pain had BNP levels measured at the time of presentation. The AUC of BNP for diagnosis of AMI, diagnosis of ACS and occurrence of adverse events (death, AMI or coronary revascularisation) within 30 days was $0.766,0.691$ and 0.675 respectively. The authors incorporated BNP into a multimarker strategy that also included CK-MB, myoglobin and troponin I. Using serial estimations at the time of ED presentation and 90 minutes later, this multimarker panel had a sensitivity of $97.4 \%$ (95\% CI $86.5-100.0 \%)$, specificity $47.8 \%$ (42.7 - 52.9\%), PPV 15.8\% (11.5 - 21.1\%) and NPV 99.5\% (97.0 - 100.0\%) for diagnosis of AMI. For a diagnosis of ACS performance was slightly worse, with a sensitivity 
of $88.1 \%$ and NPV $92.9 \%$ and for predicting adverse events within 30 days the panel performed with sensitivity $88.5 \%$, specificity $43.9 \%$, PPV $18.0 \%$ and NPV $96.5 \%$ (230). The available evidence suggests that BNP may have value as a diagnostic and prognostic marker in patients who present to the ED with suspected ACS. However it is readily apparent that BNP is unsuitable for use as a lone biomarker in this situation. Future research is still necessary in order to define the potential role of BNP as part of a multimarker strategy.

\subsection{Novel markers of myocardial necrosis}

\subsubsection{Heart-type Fatty Acid Binding Protein (H-FABP)}

$\mathrm{H}-\mathrm{FABP}$ is a cytoplasmic protein that is abundantly expressed in human myocardial cells. It is also found in much lower concentration in skeletal muscle, kidney and brain tissue (231). Experimental data first suggested that H-FABP may be a potential novel biomarker of AMI as early as 1988 (232). In 1991 Tanaka et al reported elevated H-FABP levels in patients with AMI, with levels peaking earlier than CK-MB (233). Despite interest in H-FABP as an early marker of AMI for many years it has never gained widespread acceptance for use in clinical practice.

Five studies have investigated the diagnostic utility of H-FABP when used for the diagnosis of AMI at the time of presentation to the ED (234-238). Four of these studies utilised qualitative assays that are available as point of care tests. All five studies had significant weaknesses, with most studies employing now outdated gold standards for AMI diagnosis and being subject to significant verification bias. The data reporting in the small study by Alashemi et al precludes calculation of total sensitivity and specificity (235). If the remainder of the results are pooled this would give H-FABP a total sensitivity of 70.0\% (95\% CI 66.0 $73.7 \%)$ and a total specificity of $80.7 \%$ (78.1 - 83.0). Excluding the study by Ghani et al, in which a quantitative assay was used, the pooled sensitivity is $76.8 \%(72.6-80.5 \%)$, pooled specificity $72.5 \%$ (68.9 - 75.8\%), pooled PPV 65.8\% (61.6 - 69.8\%) and pooled NPV $82.0 \%$ (78.6-85.0\%). The positive likelihood ratio would be 2.79 and negative likelihood ratio 0.32 . It should be acknowledged that pooling results in this manner does not take account of heterogeneity and is inferior to a formal meta-analysis. However, assuming that these statistics are a true reflection of the performance of H-FABP, if we were to apply the test in a typical United Kingdom ED population with suspected cardiac chest pain who have a prevalence of AMI of approximately $18 \%$, the post-test probability of AMI given a normal H-FABP test would be $6.6 \%$. This provides similar predictive value to a normal ECG in this cohort (239) but is still far from excluding the diagnosis.

\section{Multimarker strategy}

Previous work from our own group, investigating heart fatty acid binding protein $(\mathrm{H}-$ FABP), CK-MB, myoglobin, cTnI, BNP, D-dimer, neutrophil gelatinase associated lipocalin (NGAL) and myeloperoxidase, in 705 patients presenting to the emergency department demonstrated that no single biomarker could exclude AMI. However multivariate analysis identified cTnI and H-FABP as an optimal biomarker combination. When combined with clinical risk stratification, the strategy exhibited a sensitivity of $96.9 \%$, specificity of $54 \%$ and negative predictive value of $98 \%$. [240]. 
The utility of a multimarker strategy must also be considered in the light of developments in assays. We have evaluated a high sensitivity troponin $\mathrm{T}$ assay in 915 patients, where the results demonstrated a negative predictive value of $99.4 \%$. [241]

\section{Conclusion}

In recent years there has been substantial and growing interest in a number of novel biomarkers that may facilitate early diagnosis of AMI and enhanced risk stratification of patients who present to the ED with suspected ACS. Promising markers of each step in the pathophysiological evolution of an acute coronary syndrome have been identified, each of which may be detected in the peripheral circulation. Unfortunately it is unlikely that any of these biomarkers will be as cardio-specific as the cardiac troponins and, despite considerable research, there is at present no single biomarker that can be used to confirm or exclude a diagnosis of ACS in the ED. If there is to be a future for novel biomarkers in the ED diagnosis of ACS, therefore, future research must focus on incorporating levels of multiple biomarkers and available clinical information into a risk score or clinical decision rule, in order that the predictive value of individual biomarkers and clinical features may be combined and enhanced.

\section{References}

[1] British Heart Foundation. Mortality statistics 2004. www.heartstats.com . 2005. Ref Type: Generic

[2] Allender S, Peto V, Scarborough P, Boxer A, Rayner M. Coronary Heart Disease Statistics. 15th ed. London: British Heart Foundation; 2007.

[3] Fothergill NJ, Hunt MT, Touquet R. Audit of patients with chest pain presenting to an accident and emergency department over a 6-month period. Archives of Emergency Medicine 1993;10:155-60.

[4] Ekelund U, Nilsson HJ, Frigyesi A, Torffvit O. Patients with suspected acute coronary syndrome in a university hospital emergency department: an observational study. BMC Emergency Medicine 2002;2(1).

[5] Blatchford O, Capewell S, Murray S, Blatchford M. Emergency medical admission in Glasgow: general practices vary despite adjustment for age, sex and deprivation. British Journal of General Practice 1999;49:551-4.

[6] Collinson P, Premachandram S, Hashemi K. Prospective audit of incidence of prognostically important myocardial damage in patients discharged from emergency department. British Medical Journal 2000;320:1702-5.

[7] Pope JH, Aufderheide TP, Ruthazer R, Woolard RH, Feldman JA, Beshansky JR, et al. Missed diagnoses of acute cardiac ischaemia in the Emergency Department. N Engl J Med 2000;342:1163-70.

[8] Obrastzow WP, Straschesko ND. Zur Kenntnis der Thrombose der Koronararterien des Herzens. Z Klin Med 1910;71:116-32.

[9] Herrick JB. Clinical features of sudden obstruction of the coronary arteries. JAMA 1912;59:2015-20. 
[10] Classics in arteriosclerosis research: an experimental cholesterin steatosis and its significance in the origin of some pathological processes by N. Anitschkow and S. Chalatow, translated by Mary Z. Pelias. Arteriosclerosis 1938;3:178-82.

[11] Stary HC, Chandler AB, Dinsmore RE, Fuster V, Glagov S, Insull W, et al. A definition of advanced types of atherosclerotic lesions and a histological classification of atherosclerosis. Circulation 1995;92:1355-74.

[12] Yokoya K, Takatsu H, Suzuki T, Hosokawa H, Ojio S, Matsubara T, et al. Process of progression of coronary artery lesions from mild or moderate stenosis to moderate or severe stenosis. A study based on four serial coronary arteriograms per year. Circulation 1999;100:903-9.

[13] Giroud D, Li JM, Urban P, Meier B, Rutishauser W. Relation of the site of acute myocardial infarction to the most severe coronary arterial stenosis at prior angiography. American Journal of Cardiology 1992;69:729-32.

[14] Little WC, Constantinescu M, Applegate RJ, Kutcher MA, Burrows MT, Kahl FR, et al. Can coronary angiography predict the site of subsequent myocardial infarction in patients with mild-to-moderate coronary artery disease? Circulation 1988;78:1157-66.

[15] Davies MJ. Stability and instability: two faces of coronary atherosclerosis. The Paul Dudley White Lecture 1995. Circulation 1996;94(8):2013-20.

[16] Kher N, Marsh JD. Pathobiology of atherosclerosis - a brief review. Seminars in Thrombosis and Haemostasis 2004;30(6):665-72.

[17] Libby P. Molecular bases of the acute coronary syndromes. Circulation 1995;91:284450.

[18] Glagov S, Weisenberd E, Zrins C, Stankunavicius R, Kolettis G. Compensatory enlargement of human atherosclerotic coronary arteries. New England Journal of Medicine 1987;316:1371-5.

[19] Ge J, Erbel R, Gerber T, Gorge G, Koch L, Haude M, et al. Intravascular ultrasound imaging of angiographically normal coronary arteries: a prospective study in vivo. British Heart Journal 1994;71(6):572-8.

[20] Ge J, Erbel R, Zamorano J, Koch L, Kearney P, Gorge G, et al. Coronary artery remodelling in atherosclerotic disease: an intravascular ultrasound study in vivo. Coronary Artery Disease 1993;4:981-6.

[21] Losordo DW, Rosenfield K, Kaufman J, Pieczek A, Isner JM. Focal compensatory enlargement of human arteries in response to progressive atherosclerosis: in vivo documentation using intravascular ultrasound. Circulation 1994;89:2570-7.

[22] Libby P, Ridker PM. Inflammation and atherothrombosis: From population biology and bench research to clinical practice. Journal of the American College of Cardiology 2006;48(9 Suppl A):33-46.

[23] Szmitko PE, Wang CH, Weisel RD, de Almeida JR, Anderson TJ, Verma S. New markers of inflammation and endothelial cell activation Part 1. Circulation 2003;108:1917-23.

[24] Szmitko PE, Wang CH, Weisel RD, Jeffries GA, Anderson TJ, Verma S. Biomarkers of vascular disease linking inflammation to endothelial activation. Part 2. Circulation 2003;108(17):2041-8.

[25] Libby P, Ridker PM, Maseri A. Inflammation and atherosclerosis. Circulation 2002;105:1135-43. 
[26] Behrendt D, Ganz P. Endothelial function: from vascular biology to clinical applications. American Journal of Cardiology 2002;90(Suppl):40L-8L.

[27] Ross R. Atherosclerosis - an inflammatory disease. N Engl J Med 1999;340(2):115-26.

[28] Hoppeler H, Kayar SR. Capillarity and oxidative capacity of muscle. News in Physiolical Science 1988;3:113-6.

[29] Bevilacqua MP. Endothelial-leukocyte adhesion molecules. Annual Reviews of Immunology 1993;11:767-804.

[30] Weissman G. The role of neutrophils in vascular injury: a summary of signal transduction mechanisms in cell/cell interactions. Springer Seminars in Immunopathology 1989;11:235-58.

[31] Gauthier TW, Scalia R, Murohara T, Guo JP, Lefer AM. Nitric oxide protects against leukocyte-endothelium interactions in the early stages of hypercholesterolaemia. Arteriosclerosis, Thrombosis \& Vascular Biology 1995;15:1652-9.

[32] Kubes P, Suzuki M, Granger DN. Nitric oxide: an endogenous modulator of leukocyte adhesion. Proceedings of the National Academy of Sciences USA 1991;88:4651-5.

[33] Cornwell TL, Arnold E, Boerth NJ, Lincoln TM. Inhibition of smooth muscle cell growth by nitric oxide and activation of cAMP-dependent protein kinase by cGMP. American Journal of Physiology 1994;267:C1405-C1413.

[34] de Graaf JC, Banga JD, Moncada S, Palmer RM, de Groot PG, Sixma JJ. Nitric oxide functions as an inhibitor of platelet adhesion under flow conditions. Circulation 1992;85:2284-90.

[35] Springer TA. Traffic signals for lymphocyte recirculation and leukocyte emigration: the multistep paradigm. Cell 1994;76:301-14.

[36] Adams DH, Lloyd AR. Chemokines: leukocyte recruitment and activation cytokines. Lancet 1997;349:490-5.

[37] Gearing AJH, Newman W. Circulating adhesion molecules in disease. Immunology Today 1993;14(10):506-12.

[38] Price DT, Loscalzo J. Cellular adhesion molecules and atherogenesis. American Journal of Medicine 1999;107:85-97.

[39] Tiong AY, Brieger D. Inflammation and coronary artery disease. American Heart Journal 2005;150(1):11-8.

[40] Podrez EA, Febbraio M, Sheibani N, Schmitt D, Silberstein RL, Hajjar DP, et al. Macrophage scavenger receptor CD36 is the major receptor for LDL modified by monocyte-generated reactive nitrogen species. Journal of Clinical Investigation 2000;105:1095-108.

[41] Podrez EA, Schmitt D, Hoff HF, Hazen SL. Myeloperoxidase-generated reactive nitrogen species convert LDL into an atherogenic form in vivo. Journal of Clinical Investigation 1999;103:1547-60.

[42] Fu X, Kassim SY, Parks WC, Heinecke JW. Hypochlorous acid oxygenates the cysteine switch domain of pro-matrilysn (MMP-7). J Biol Chem 2001;276(44):41279-87.

[43] Sugiyama S, Okada Y, Sukhova GK, Virmani R, Heinecke JW, Libby P. Macrophage myeloperoxidase regulation by granulocyte macrophage colony-stimulating factor in human atherosclerosis and implications in acute coronary syndromes. American Journal of Pathology 2001;158(3):879-91. 
[44] Schonbeck U, Libby P. The CD40/CD154 receptor/ligand dyad. Cellular and Molecular Life Sciences 2001;58:4-43.

[45] Mach F, Schonbeck U, Sukhova GK, Bourcier T, Bonnefoy JY, Pober JS, et al. Functional CD40 ligand is expressed on human vascular endothelial cells, smooth muscle cells, and macrophages: Implications for CD40-CD40 ligand signaling in atherosclerosis. PNAS 1997 Mar 4;94(5):1931-6.

[46] Urbich C, Dernbach E, Aicher A, Zeiher AM, Dimmeler S. CD40 ligand inhibits endothelial cell migration by increasing production of endothelial reactive oxygen species. Circulation 2002;106:981-6.

[47] Schonbeck U, Sukhova GK, Shimizu K, Mach F, Libby P. Inhibition of CD40 signalling limits evolution of established atherosclerosis in mice. PNAS 2000;97(13):7458-63.

[48] Peng DQ, Zhao SP, Li YF, Li J, Zhou HN. Elevated soluble CD40 ligand is related to the endothelial adhesion molecules in patients with acute coronary syndromes. Clinica Chimica Acta 2002;319:19-26.

[49] Schonbeck U, Libby P. CD40 signaling and plaque instability. Circulation Research 2001;89:1092-103.

[50] Lindmark E, Tenno T, Siegbahn A. Role of platelet P-selectin and CD40 ligand in the induction of monocytic tissue factor expression. Arteriosclerosis, Thrombosis \& Vascular Biology 2000;20:2322-8.

[51] Geng YJ, Libby P. Progression of atheroma: a struggle between death and procreation. Arteriosclerosis, Thrombosis \& Vascular Biology 2002;22:1370-80.

[52] van Zanten GH, de Graaf S, Slootweg PJ, Heijnen HFG, Connolly TM, de Groot PG, et al. Increased platelet deposition on atherosclerotic coronary arteries. Journal of Clinical Investigation 1994;93:615-32.

[53] van der Wal AC, Becker AE, van der Loos CM, Das PK. Site of intimal rupture or erosion of thrombosed coronary atherosclerotic plaques is characterized by an inflammatory process irrespective of the dominant plaque morphology. Circulation 1994;89:36-44.

[54] Bayes-Genis A, Conover CA, Overgaard MT, Bailey KR, Christiansen M, Holmes DR, et al. Pregnancy-associated plasma protein A as a marker of acute coronary syndromes. New England Journal of Medicine 2001;345(14):1022-9.

[55] Virmani R, Burke AP, Farb A, Kolodgie FD. Pathology of the vulnerable plaque. Journal of the American College of Cardiology 2006;47:C13-C18.

[56] Davies MJ. A macro and micro view of coronary vascular insult in ischemic heart disease. Circulation 1990;82(Suppl 1):I-1138-I-1146.

[57] Farb A, Burke AP, Tang AL, Liang Y, Mannan P, Smialek J, et al. Coronary plaque erosion without rupture into a lipid core: a frequent cause of coronary thrombosis in sudden coronary death. Circulation 1996;93:1354-63.

[58] Cheng G, Loree H, Kamm R, Fishbein M, Lee R. Distribution of circumferential stress in ruptured and stable atherosclerotic lesions: a structural analysis with histopathological correlation. Circulation 1993;87:1179-87.

[59] Richardson P, Davies M, Born G. Influence of plaque configuration and stress distribution on fissuring of coronary atherosclerotic plaques. Lancet 1989;334(8669):941-4. 
[60] Muller JE, Abela GS, Nesto RW, Tofler GH. Triggers, acute risk factors and vulnerable plaques: the lexicon of a new frontier. Journal of the American College of Cardiology 1994;23:809-13.

[61] Shah PK. Plaque disruption and coronary thrombosis: new insight into pathogenesis and prevention. Clin Cardiol 1997;20(Suppl II):II-38-II-44.

[62] Andre P, Prasad S, Denis CV, He M, Papalia JM, Hynes RO, et al. CD40L stabilizes arterial thrombi by a beta3 integrin-dependent mechanism. Nature Medicine 2002;8(3):247-52.

[63] Merten M, Chow T, Hellums JD, Thiagarajan P. A New Role for P-Selectin in ShearInduced Platelet Aggregation. Circulation 2000;102(17):2045-50.

[64] Merten M, Thiagarajan P. P-Selectin Expression on Platelets Determines Size and Stability of Platelet Aggregates. Circulation 2000;102(16):1931-6.

[65] Blann AD, Nadar SK, Lip GYH. The adhesion molecule P-selectin and cardiovascular disease. European Heart Journal 2003;24:2166-79.

[66] Viallard JF, Solanilla A, Gauthier B, Contin C, Dechanet J, Grosset C, et al. Increased soluble and platelet-associated CD40 ligand in essential thrombocythemia and reactive thrombocytosis. Blood 2002;99:2612-4.

[67] Davies M, Bland J, Hangartner J, Angelini A, Thomas A. Factors influencing the presence or absence of acute coronary artery thrombi in sudden ischemic death. European Heart Journal 1989;10:203-8.

[68] Davies M, Thomas A. Thrombosis and acute coronary artery lesions in sudden cardiac ischemic death. New England Journal of Medicine 1984;310:1137-40.

[69] Frink R. Chronic ulcerated plaques: new insights into the pathogenesis of acute coronary disease. Journal of Invasive Cardiology 1994;6:173-85.

[70] Falk E. Plaque rupture with severe pre-existing stenosis precipitating coronary thrombosis. British Heart Journal 1983;1983(50):-127.

[71] Willerson JTGP, Eidt J, Campbell WB, Buja M. Specific platelet mediators and unstable coronary artery lesions: experimental evidence and potential clinical imlications. Circulation 1989;80:198-205.

[72] Ferguson JL, Beckett GJ, Stoddart M, Walker SW, Fox KAA. Myocardial infarction redefined: the new ACC/ESC definition, based on cardiac troponin, increases the apparent incidence of infarction. Heart 2002;88:343-7.

[73] Johnson-Tidey RR, McGregor JL, Taylor PR, Poston RN. Increase in the adhesion molecule P-selectin in endothelium overlying atherosclerotic plaques. American Journal of Pathology 1994;144(5):952-61.

[74] Koyama H, Maeno T, Fukumoto S, Shoji T, Yamane T, Yokoyama H, et al. Platelet Pselectin expression is associated with atherosclerotic wall thickness in carotid artery in humans. Circulation 2003;2003(108):-524.

[75] Tenaglia AN, Buda AJ, Wilkins RG, et al. Levels of expression of P-selectin, E-selectin and inter cellular adhesion molecule- 1 in coronary atherectomy specimens from patients with stable and unstable angina pectoris. American Journal of Cardiology 1997;79:742-7.

[76] Hsu-Lin S, Berman CL, Furie BC, August D, Furie B. A platelet membrane protein expressed during platelet activation and secretion. Studies using a monoclonal antibody specific for thrombin- activated platelets. J Biol Chem 1984;259(14):9121-6. 
[77] Shimomura H, Ogawa H, Arai H, Moriyama Y, Takazoe K, Hirai N, et al. Serial changes in plasma levels of soluble P-selectin in patients with acute myocardial infarction. American Journal of Cardiology 1998;81:397-400.

[78] Ikeda H, Nakayama H, Oda T, Kuwano K, Muraishi A, Sugi K, et al. Soluble form of Pselectin in patients with acute myocardial infarction. Coronary Artery Disease 1994;5(6):515-8.

[79] Gurbel PA, O'Connor CM, Dalesandro MR, Serebruany VL. Relation of soluble and platelet P-selectin to early outcome in patients with acute myocardial infarction after thrombolytic therapy. American Journal of Cardiology 2001;87(15):774-7.

[80] Mulvihill NT, Foley JB, Murphy R, Crean P, Walsh M. Evidence of prolonged inflammation in unstable angina and non-Q wave myocardial infarction. Journal of the American College of Cardiology 2000;36(4):1210-6.

[81] Xu DY, Zhao SP, Peng WP. Elevated plasma levels of soluble P-selectin in patients with acute myocardial infarction and unstable angina: An inverse link to lipoprotein(a). International Journal of Cardiology 1998;64:253-8.

[82] Guray U, Erbay AR, Guray Y, Yilmaz B, Boyaci AA, Sasmaz H, et al. Levels of soluble adhesion molecules in various clinical presentations of coronary atherosclerosis. International Journal of Cardiology 2004;96:235-40.

[83] Chiu CA, Wu CJ, Yang CH, Fang CY, Hsieh YK, Hang CL, et al. Levels and value of soluble P-selectin following acute myocardial infarction: evaluating the link between soluble P-selectin levels and recruitment of circulating white blood cells and the marker for the rapid diagnosis of chest pain. Chang Gung Medical Journal 28(10):699-707, 2005.

[84] Liu WH, Yang CH, Yeh KH, Chang HW, Chen YH, Chen SM, et al. Circulating levels of soluble P-selectin in patients in the early and recent phases of myocardial infarction. Chang Gung Medical Journal 28(9):613-20, 2005.

[85] Atalar E, Aytemir K, Haznedaroglu I, Ozer N, Ovunc K, Aksoyek S, et al. Increased plasma levels of soluble selectins in patients with unstable angina. International Journal of Cardiology 2001;78:69-73.

[86] Ikeda H, TAkajo Y, Ichiki K, Ueno T, Maki S, Noda T, et al. Increased soluble form of P-selectin in patients with unstable angina. Circulation 1995;92:1693-6.

[87] Parker C 3rd, Vita JA, Freedman JE. Soluble adhesion molecules and unstable coronary artery disease. Atherosclerosis 2001;156(2):417-24.

[88] Venturinelli ML, Hovnan A, Soeiro AM, Nicolau JC, Ramires JA, D'Amico EA, et al. Platelet activation in different clinical forms of the coronary artery disease (role of P-selectin and others platelet markers in stable and unstable angina). Arquivos Brasileiros de Cardiologia 2006;87(4):446-50.

[89] Ault KA, Cannon CP, Mitchell J, McCahan J, Tracy RP, Novotny WF, et al. Platelet activation in patients after an acute coronary syndrome: Results from the TIMI-12 trial. Journal of the American College of Cardiology 1999;33:634-9.

[90] Itoh T, Nakai K, Ono M, Hiramori K. Can the risk for acute cardiac events in acute coronary syndrome be indicated by platelet membrane activation marker Pselectin? Coronary Artery Disease 1995;6(8):645-50. 
[91] Mulvihill NT, Foley JB, Murphy RT, Curtin R, Crean PA, Walsh M. Risk stratification in unstable angina and non-q wave myocardial infarction using soluble cell adhesion molecules. Heart 2001;85:623-7.

[92] Soeki T, Tamura Y, Shinohara H, Sakabe K, Onose Y, Fukuda N. Increased soluble platelet/endothelial cell adhesion molecule- 1 in the early stages of acute coronary syndromes. International Journal of Cardiology 2003;90:261-8.

[93] Kavsak PA, Ko DT, Newman AM, Lustig V, Palomaki GE, Macrae AR, et al. Vascular versus myocardial dysfunction in acute coronary syndrome: Are the adhesion molecules as powerful as NT-proBNP for long-term risk stratification? Clinical Biochemistry 2008;6:436-9.

[94] Serebruany VL, Murugesan SR, Pothula A, Semaan H, Gurbel PA. Soluble PECAM-1, but not P-selectin, nor osteonectin identify acute myocardial infarction in patients presenting with chest pain. Cardiology 1999;91(1):50-5.

[95] Serebruany VL, Levine DJ, Nair GV, Meister AF, Gurbel PA. Usefulness of combining necrosis and platelet markeres in triaging patients presenting with chest pain to the Emergency Department. Journal of Thrombosis and Thrombolysis 2001;11:155-62.

[96] Hillis GS, Terregino C, Taggart P, Killian A, Zhao N, Dalsey WC, et al. Elevated soluble P-selectin levels are associated with an increased risk of early adverse events in patients with presumed myocardial ischemia. American Heart Journal 2002;143:235-41.

[97] Hollander JE, Muttreja R, Dalesandro MR, Shofer FS. Risk stratification of emergency patients with acute coronary syndromes using P-selectin. Journal of the American College of Cardiology 1999;34:95-105.

[98] Gurbel PA, Kereiakes DJ, Dalesandro MR, et al. Role of soluble and platelet bound Pselectin in discriminating cardiac from non cardiac chest pain at presentation in the emergency department. American Heart Journal 2000;139:320-8.

[99] R, Pemberton P, Ali F et al. Low soluble P-selectin may facilitate early exclusion of acute myocardial infarction. Clin Chem Acta 2011; 412: 614-8

[100] Oishi Y, Wakatsuki T, Nishikado A, Oki T, Ito S. Circulating adhesion molecules and severity of coronary atherosclerosis. Coronary Artery Disease 2000;11(1):77-81.

[101] Squadrito F, Altavilla D, Ioculano M, Canale P, Campo GM, Squadrito G, et al. Soluble E-selectin levels in acute human myocardial infarction. International Journal of Microcirculation: Clinical \& Experimental 1995;15(2):80-4.

[102] Miyao Y, Miyazaki S, Goto Y, Itoh A, Daikoku S, Morli I, et al. Role of cytokines and adhesion molecules in ischemia and reperfusion in patients with acute myocardial infarction. Japanese Circulation Journal 1999;63(5):362-5.

[103] Zeitler H, Ko Y, Zimmerman C, Nickenig G, Glanzer K, Walger P, et al. Elevated serum concentrations of soluble adhesion molecules in coronary artery disease and acute myocardial infarction. European Journal of Medical Research 1997;2(9):389-94.

[104] Li YH, Teng JK, Tsai WC, Lin LJ, Chen JH. Elevated levels of soluble adhesion molecules is associated with the severity of myocardial damage in acute myocardial infarction. American Journal of Cardiology 1997;80:1218-21.

[105] Suefuji H, Ogawa H, Yasue H, Sakamoto T, Miyao Y, Kaikita K, et al. Increased plasma level of soluble E-selectin in acute myocardial infarction. American Heart Journal 2000;140:243-8. 
[106] Pellegatta F, Pizzetti G, Lu Y, Radaelli A, Pomes D, Carlino M, et al. Soluble E-selectin and intercellular adhesion molecule-1 plasma levels increase during acute myocardial infaction. J Cardiovasc Pharmacol 1997;30(4):455-60.

[107] Siminiak T, Dye JF, Egdell RM, More R, Wysocki H, Sheridan DJ. The release of soluble adhesion molecules ICAM-1 and E-selectin after acute myocardial infarction and following coronary angioplasty. International Journal of Cardiology 1997;61(2):113-8.

[108] Squadrito F, Saitta A, Altavilla D, Ioculano M, Canale P, Campo GM, et al. Thrombolytic therapy with urokinase reduces increased circulating endothelial adhesion molecules in acute myocardial infarction. Inflammation Research 1996;45(1):14-9.

[109] Ghaisas NK, Shahi CN, Foley B, Goggins M, Crean P, Kelly A, et al. Elevated levels of circulating soluble adhesion molecules in peripheral blood of patients with unstable angina. American Journal of Cardiology 1997;80:617-9.

[110] Xie Y, Zhou T, Shen W, Lu G, Yin T, Gong L. Soluble cell adhesion molecules in patients with acute coronary syndrome. Chinese Medical Journal 2000;113(3):286-8.

[111] Mulvihill N, Foley JB, Ghaisas N, Murphy R, Crean P, Walsh M. Early temporal expression of soluble cellular adhesion molecules in patients with unstable angina and subendocardial myocardial infarction. American Journal of Cardiology 1999;83:1265-7.

[112] Boos CJ, Balakrishnan B, Blann AD, Lip GYH. The relationship of circulating endothelial cells to plasma indices of endothelial damage/dysfunction and apoptosis in acute coronary syndromes: Implications for prognosis. Journal of Thrombosis and Haemostasis 2008;6(11):1841-50.

[113] Miwa K, Igawa A, Inoue H. Soluble E-selectin, ICAM-1 and VCAM-1 levels in systemic and coronary circulation in patients with variant angina. Cardiovascular Research 1997;36(1):37-44.

[114] Siminiak T, Smielecki J, Dye JF, Balinski M, El-Gendi H, Wysocki H, et al. Increased release of the soluble form of the adhesion molecules L-selectin and ICAM-1 but not E-selectin during attacks of angina pectoris. Heart \& Vessels 1998;13(4):189-94.

[115] Gurbel PA, Serebruany VL. Soluble vascular cell adhesion molecule-1 and E-selectin in patients with acute myocardial infarction treated with thrombolytic agents. American Journal of Cardiology 1998;81:772-5.

[116] Galvani M, Ferrini D, Ottani F, Nanni C, Ramberti A, Amboni P, et al. Soluble Eselectin is not a marker of unstable coronary plaque in serum of patients with ischemic heart disease. Journal of Thrombosis \& Thrombolysis 2000;9(1):53-60.

[117] Shyu KG, Chang H, Lin CC, Kuan P. Circulating intercellular adhesion molecule-1 and E-selectin in patients with acute coronary syndrome. Chest 1996;109:1627-30.

[118] Hope SA, Meredith IT, Farouque HMO, Worthley SG, Plunkett JC, Balazs ND. Time course of plasma adhesion molecules in acute coronary syndromes. Coronary Artery Disease 2002;13:215-21.

[119] Ridker PM, Hennekens CH, Roitman-Johnson B, Stampfer MJ, Allen J. Plasma concentration of soluble intercellular adhesion molecule-1 and risks of future myocardial infarction in apparently healthy men. Lancet 1998;351:88-92. 
[120] Luc G, Arveiler D, Evans A, Amouyel P, Ferrieres J, Bard MJ, et al. Circulating soluble adhesion molecules ICAM-1 and VCAM-1 and incident coronary heart disease: The PRIME Study. Atherosclerosis 2003;170:169-76.

[121] Empana J-P, Canoui-Poitrine F, Luc G, Juhan-Vague I, Morange P, Arveiler D, et al. Contribution of novel biomarkers to incident stable angina and acute coronary syndrome: The PRIME Study. European Heart Journal 2008;29(16):1966-74.

[122] Ridker PM, Hennekens CH, Buring JE, Rifai N. C-reactive protein and other markers of inflammation in the prediction of cardiovascular disease in women. New England Journal of Medicine 2000;3442:836-43.

[123] Shai I, Pischon T, Hu FB, Ascherio A, Rifai N, Rimm EB. Soluble intercellular adhesion molecules, soluble vascular cell adhesion molecules, and risk of coronary heart disease. Obesity 2006;14(11):2099-106.

[124] Albert MA, Glynn RJ, Buring JE, Ridker PM. Differential effect of soluble intercellular adhesion molecule- 1 on the progression of atherosclerosis as compared to arterial thrombosis: a prospective analysis of the Women's Health Study. Atherosclerosis 1997;(1):297-302.

[125] Morisaki N, Saito I, Tamura K, Tashiro J, Masuda M, Kanzaki T, et al. New indices of ischemic heart disease and aging: studies on the serum levels of soluble intercellular adhesion molecule-1 (ICAM-1) and soluble vascular cell adhesion molecules-1 (VCAM-1) in patients with hypercholesterolemia and ischemic heart disease. Atherosclerosis 1997;131:43-8.

[126] Haim M, Tanne D, Boyko V, Reshef T, Goldbourt U, Leor J, et al. Soluble intercellular adhesion molecule- 1 and long-term risk of acute coronary events in patients with coronary heart disease. Journal of the American College of Cardiology 2002;39(7):1133-8.

[127] Wallen NH, Held C, Rehnqvist N, Hjemdahl P. Elevated serum intercellular adhesion molecule- 1 and vascular adhesion molecule- 1 among patients with stable angina pectoris who suffer cardiovascular death or non-fatal myocardial infarction. European Heart Journal 1999;20:1039-43.

[128] Postadzhiyan AS, Tzontcheva AV, Kehayov I, Finkov B. Circulating soluble adhesion molecules ICAM-1 and VCAM-1 and their association with clinical outcome, troponin $\mathrm{T}$ and $\mathrm{C}$-reactive protein in patients with acute coronary syndromes. Clinical Biochemistry 2008;41(3):126-33.

[129] Tousoulis D, Antoniades C, Bosinakou E, Kotsopoulou M, Tsoufis C, Marinou K, et al. Differences in inflammatory and thrombotic markers between unstable angina and acute myocardial infarction. International Journal of Cardiology 115(2):203-7, 2007 Feb 7.

[130] Tekin G, Tekin A, Sipahi I, Kaya A, Sansoy V. Plasma concentration of soluble vascular cell adhesion molecule-1 and oncoming cardiovascular risk in patients with unstable angina pectoris and non-ST-segment elevation myocardial infarction. American Journal of Cardiology 2005;96(3):379-81.

[131] Chen WQ, Zhang M, Ji XP, Ding SF, Zhao YX, Chen YG, et al. Usefulness of highfrequency vascular ultrasound imaging and serum inflammatory markers to predict plaque rupture in patients with stable and unstable angina pectoris. American Journal of Cardiology 2007;100(9):1341-6. 
[132] Hartford M, Wiklund O, Mattsson HL, Persson A, Karlsson T, Herlitz J, et al. Creactive protein, interleukin-6, secretory phospholipase A2 group IIA and intercellular adhesion molecule- 1 in the prediction of late outcome events after acute coronary syndromes. Journal of Internal Medicine 2007;262(5):526-36.

[133] Rallidis LS, Gika HI, Zolindaki MG, Xydas TA, Paravolidakis KE. Usefulness of elevated levels of soluble vascular cell adhesion molecule- 1 in predicting inhospital prognosis in patients with unstable angina pectoris. American Journal of Cardiology 2003;92(10):1195-7.

[134] Murphy RT, Foley JB, Mulvihill N, Crean P, Walsh MJ. Endothelial inflammation and thrombolysis resistance in acute myocardial infarction. International Journal of Cardiology 2002;83:227-31.

[135] Parissis JT, Adamopoulous S, Venetsanou K, Kostakis G, Rigas A, Karas SM, et al. Plasma profiles of circulating granulocyte-macrophages colony-stimulating factor and soluble cellular adhesion molecules in acute myocardial infarction. Contribution to post-infarction left ventricular dysfunction. European Cytokine Network 2004;15(2):139-44.

[136] Murohara T, Kamijikkoku S, Honda T. Increased circulating soluble intercellular adhesion molecule- 1 in acute myocardial infarction: A possible predictor of reperfusion ventricular arrhythmias. Critical Care Medicine 2000;28(6):1861-4.

[137] Kamijikkoku S, Murohara T, Tayama S, Matsuyama K, Honda T, Ando M, et al. Acute myocardial infarction and increased soluble intercellular adhesion molecule-1: A marker of vascular inflammation and a risk of early restenosis? American Heart Journal 1998;136(2):231-6.

[138] O'Malley TO, Ludlam CA, Tiemermsa RA, Fox KAA. Early increase in levels of soluble inter-cellular adhesion molecule-1 (sICAM-1). Potential risk factor for the acute coronary syndromes. European Heart Journal 2001;22:1226-34.

[139] Menown IBA, Mathew TP, Gracey HM, Nesbitt GS, Murray P, Young IS, et al. Prediction of recurrent events by D-dimer and inflammatory markers in patients with normal cardiac troponin I (PREDICT Study). American Heart Journal 2003;145:986-92.

[140] Hillis GS, Terregino C, Taggart P, Killian A, Zhao N, Kaplan J, et al. Soluble intercellular adhesion molecule- 1 as a predictor of early adverse events in patients with chest pain compatible with myocardial ischemia. Annals of Emergency Medicine 2001;38(3):223-8.

[141] Heeschen C, Dimmeler S, Hamm CW, Van den Brand MJ, Boersma E, Zeiher AM, et al. Soluble CD40 ligand in acute coronary syndromes. New England Journal of Medicine 2003;348:1104-11.

[142] Aukrust P, Muller F, Ueland T, Berget T, Aeser E, Brunsvig A, et al. Enhanced levels of soluble and membrane-bound CD40 ligand in patients with unstable angina. Possible reflection of T lymphocyte and platelet involvement in the pathogenesis of acute coronary syndromes. Circulation 1999;100(6):614-20.

[143] Garlichs CD, Eskafi S, Raaz D, Schmitdt A, Ludwig J, Herrmann M, et al. Patients with acute coronary syndromes express enhanced CD40 ligand/CD154 on platelets. Heart 2001;86:649-55. 
[144] Yan J, Wu Z, Huang Z, Li L, Zhong R, Kong X. Clinical implications of increased expression of CD40L in patients with acute coronary syndromes. Chinese Medical Journal 2002;115(4):491-3.

[145] Varo N, de Lemos JA, Libby P, Morrow DA, Murphy SA, Nuzzo R, et al. Soluble CD40L. Risk prediction after acute coronary syndromes. Circulation 2003;108:1049-52.

[146] Yan JC, Wu ZG, ?Kong XT, Zong RQ, Zhan LZ. Relation between upregulation of CD40 system and complex stenosis morphology in patients with acute coronary syndrome. Acta Pharmacologica Sinica 2004;25(2):251-6.

[147] Yan JC, Zhu J, Gao L, Wu ZG, Kong XT, Zong RQ, et al. The effect of elevated serum soluble CD40 ligand on the prognostic value in patients with acute coronary syndromes. Clinica Chimica Acta 2004;343:155-9.

[148] Tousoulis D, Antoniades C, Nikolopoulou A, Koniari K, Vasiliadou C, Marinou K, et al. Interaction between cytokines and SCD40L in patients with stable and unstable coronary syndromes. European Journal of Clinical Investigation 2007;37(8):623-8.

[149] Malarstig A, Lindahl B, Wallentin L, Siegbahn A. Soluble CD40L levels are regulated by the $-3459 \mathrm{~A}>\mathrm{G}$ polymorphism and predict myocardial infarction and the efficacy of antithrombotic treatment in non-ST elevation acute coronary syndrome. Arteriosclerosis, Thrombosis \& Vascular Biology 2006;26(7):1667-73.

[150] Yip HK, Wu CJ, Yang CH, Chang HW, Fang CY, Hung WC, et al. Serial changes in circulating concentrations of soluble CD40 ligand and C-reactive protein in patients with unstable angina undergoing coronary stenting. Circulation Journal 2005;69(8):890-5.

[151] Tan J, Hua Q, Gao J, Zhen XF. Clinical implications of elevated serum interleukin-6, soluble CD40 ligand, metalloproteinase-9, and tissue inhibitor of metalloproteinase-1 in patients with acute ST-segment elevation myocardial infarction. Clinical Cardiology 2008;31(9):413-8.

[152] Dominguez-Rodriguez A, breu-Gonzalez P, Garcia-Gonzalez MJ, Kaski JC. Soluble CD40 ligand:interleukin-10 ratio predicts in-hospital adverse events in patients with ST-segment elevation myocardial infarction.[see comment]. Thrombosis Research 121(3):293-9, 2007.

[153] Apple FS, Pearce LA, Chung A, Ler R, Murakami MM. Multiple biomarker use for detection of adverse events in patients presenting with symptoms suggestive of acute coronary syndrome. Clinical Chemistry 2007;53(5):874-81.

[154] Brugger-Andersen T, Aarsetoy H, Grundt H, Staines H, Nilsen DWT. The long-term prognostic value of multiple biomarkers following a myocardial infarction. Thrombosis Research 2008;123(1):60-6.

[155] Abu-Soud HM, Hazen SL. Nitric oxide is a physiological substrate for mammalian peroxidases. J Biol Chem 2000;275(48):37524-32.

[156] Podrez EA, Poliakov E, Shen Z, Zhang R, Deng Y, Sun M, et al. A novel family of atherogenic oxidized phospholipids promotes macrophage foam cell formation via the scavenber receptor CD36 and is enriched in atherosclerotic lesions. J Biol Chem 2002;277(41):38517-23.

[157] Biasucci LM, D'Onofrio G, Liuzzo G, Zini G, Monaco C, Caligiuri G, et al. Intracellular neutrophil myeloperoxidase is reduced in unstable angina and acute myocardial 
infarction, but its reduction is not related to ischemia. Journal of the American College of Cardiology 1996;27(3):611-6.

[158] Zhang R, Brennan ML, Fu X, Aviles RJ, Pearce GL, Penn MS, et al. Association between myeloperoxidase levels and risk of coronary artery disease. JAMA 2001;2886:213642.

[159] Ndrepepa G, Braun S, Mehilli J, von BN, Schomig A, Kastrati A. Myeloperoxidase level in patients with stable coronary artery disease and acute coronary syndromes. European Journal of Clinical Investigation 2008;38(2):90-6.

[160] Baldus S, Heeschen C, Meinertz T, Zeiher AM, Eiserich JP, Munzel T, et al. Myeloperoxidase serum levels predict risk in patients with acute coronary syndromes. Circulation 2003;108:1440-5.

[161] Morrow DA, Sabatine MS, Brennan ML, de Lemos JA, Murphy SA, Ruff CT, et al. Concurrent evaluation of novel cardiac biomarkers in acute coronary syndrome: myeloperoxidase and soluble CD40 ligand and the risk of recurrent ischaemic events in TACTICS-TIMI 18. European Heart Journal 2008;29(9):1096-102.

[162] Khan SQ, Kelly D, Quinn P, Davies JE, Ng LL. Myeloperoxidase aids prognostication together with N-terminal pro-B-type natriuretic peptide in high-risk patients with acute ST elevation myocardial infarction. Heart 2007;93(7):826-31.

[163] Mocatta TJ, Pilbrow AP, Cameron VA, Senthilmohan R, Frampton CM, Richards AM, et al. Plasma concentrations of myeloperoxidase predict mortality after myocardial infarction.[see comment]. Journal of the American College of Cardiology 2007;49(20):1993-2000.

[164] Cavusoglu E, Ruwende C, Eng C, Chopra V, Yanamadala S, Clark LT, et al. Usefulness of baseline plasma myeloperoxidase levels as an independent predictor of myocardial infarction at two years in patients presenting with acute coronary syndrome. American Journal of Cardiology 2007;99(10):1364-8.

[165] Wang J, Xing Y, Ma C, Li S, Li Z, Gao Y, et al. Clinical correlation between myeloperoxidase and acute coronary syndrome. Journal of Geriatric Cardiology 2007;4(4):209-12.

[166] Cavusoglu E, Ruwende C, Chopra V, Yanamadala S, Eng C, Clark LT, et al. Adiponectin is an independent predictor of all-cause mortality, cardiac mortality, and myocardial infarction in patients presenting with chest pain.[see comment]. European Heart Journal 2006;27(19):2300-9.

[167] Brennan ML, Penn MS, Van Lente F, Nambi V, Shishenbor MH, Aviles RJ, et al. Prognostic value of myeloperoxidase in patients with chest pain. New England Journal of Medicine 2003;349:1595-604.

[168] Mitchell AM, Garvey JL, Kline JA. Multimarker panel to rule out acute coronary syndromes in low-risk patients. Academic Emergency Medicine 13(7):803-6, 2006 Jul.

[169] Esporcatte R, Rey HC, Rangel FO, Rocha RM, Mendonca Filho HT, Dohmann HF, et al. Predictive value of myeloperoxidase to identify high risk patients admitted to the hospital with acute chest pain. Arquivos Brasileiros de Cardiologia 2007;89(6):377-84.

[170] Newby AC. Dual role of matrix metalloproteinases (matrixins) in intimal thickening and atherosclerotic plaque rupture. Physiology Reviews 2005;85:1-31. 
[171] Henney AM, Wakeley PR, Davies MJ, Foster K, Hembry R, Murphy G, et al. Localization of Stromelysin Gene Expression in Atherosclerotic Plaques by in situ Hybridization. PNAS 1991 Sep 15;88(18):8154-8.

[172] Galis ZS, Sukhova GK, Lark MW, Libby P. Increased expression of matrix metalloproteinases and matrix degrading activity in vulnerable regions of human atherosclerotic plaque. Journal of Clinical Investigation 1994;94(6):2493-503.

[173] Wald NJ, Watt HC, Hackshaw AK. Integrated screening for Down's syndrome based on tests performed during the first and second trimesters. New England Journal of Medicine 1999;341(7):461-7.

[174] Cosin-Sales J, Christiansen M, Kaminski P, Oxvig C, Overgaard MT, Cole D, et al. Pregnancy-associated plasma protein $\mathrm{A}$ and its endogenous inhibitor, the proform of eosinophil major basic protein (proMBP), are related to complex stenosis morphology in patients with stable angina pectoris. Circulation 2004;109(14):1724-8.

[175] Laterza OF, Cameron SJ, Chappell D, Sokoll LJ, Green GB. Evaluation of pregnancyassociated plasma protein A as a prognostic indicator in acute coronary syndrome patients. Clinica Chimica Acta 2004;348:163-9.

[176] McCann CJ, Glover BM, Menown IBA, Moore MJ, McEneny J, Owens CG, et al. Novel biomarkers in early diagnosis of acute myocardial infarction compared with cardiac troponin T. European Heart Journal 2008;29(23):2843-50.

[177] Dominguez-Rodriguez A, Abreu-Gonzalez P, Garcia-Gonzalez M, Ferrer J, Vargas M. Circulating pregnancy-associated plasma protein A is not an early marker of acute myocardial infarction. Clinical Biochemistry 2005;38:180-2.

[178] Elesber AA, Lerman A, Denktas AE, Resch ZT, Jared Bunch T, Schwartz RS, et al. Pregnancy associated plasma protein-A and risk stratification of patients presenting with chest pain in the emergency department. International Journal of Cardiology 2007;117(3):365-9.

[179] Heeschen C, Dimmeler S, Hamm CW, Fichtlschere S, Simoons ML, Zeiher AM, et al. Pregnancy-associated plasma protein-A levels in patients with acute coronary syndromes: comparison with markers of systemic inflammation, platelet activation, and myocardial necrosis. Journal of the American College of Cardiology 2005;45(2):229-37.

[180] Lund J, Qin QP, Ilva T, Pettersson K, Voipio-Pulkki LM, Porela P, et al. Circulating pregnancy-associated plasma protein A predicts outcome in patients with acute coronary syndrome but no troponin I elevation. Circulation 2003;108(1924):1926.

[181] Sanchis J, Bosch X, Bodi V, Bellera N, Nunez J, Benito B, et al. Combination of clinical risk profile, early exercise testing and circulating biomarkers for evaluation of patients with acute chest pain without ST-segment deviation or troponin elevation. Heart 2008;94(3):311-5.

[182] Sadosty AT, Goyal DG, Boie ET, Chiu CK. Emergency Department D-dimer testing. Journal of Emergency Medicine 2001;21(4):423-9.

[183] Fancher TL, White RH, Kravitz RL. Combined use of rapid D-dimer testing and estimation of clinical probability in the diagnosis of deep vein thrombosis: systematic review. British Medical Journal 2004;329:821-9. 
[184] Ridker PM, Hennekens CH, Cerskus A, Stampfer MJ. Plasma concentration of crosslinked fibrin degradation product (D-dimer) and the risk of future myocardial infarction among apparently healthy men. Circulation 1994;90(5):2236-40.

[185] Danesh J, Whincup P, Walker M, Lennon L, Thomson A, Appleby P, et al. Fibrin Ddimer and coroanry heart disease: Prospective study and meta-analysis. Circulation 2001;103:2323-7.

[186] Itakura H, Sobel BE, Boothroyd D, Leung LL, Iribarren C, Go AS, et al. Do plasma biomarkers of coagulation and fibrinolysis differ between patients who have experienced an acute myocardial infarction versus stable exertional angina? American Heart Journal 2007;154(6):1059-64.

[187] Shitrit AB, Tzivony D, Shilon Y, Rudensky B, Sulkes J, Gutterer N, et al. The role of enzyme-linked immunosorbent assay D-dimer in patients with acute coronary syndrome presenting with normal cardiac enzymes. Blood Coagulation \& Fibrinolysis 2006;17(8):621-4.

[188] Shitrit D, Shitrit AB, Rudensky B, Sulkes J, Gutterer N, Zviony D. Role of ELISA Ddimer test in patients with unstable angina pectoris presenting at the Emergency Department with a normal electrocardiogram. American Journal of Haematology 2004;77(2):147-50.

[189] Shitrit D, Shitrit AB, Rudensky B, Sulkes J, Tzviony D. Determinants of ELISA D-dimer sensitivity for unstable angina pectoris as defined by coronary catheterization. American Journal of Haematology 2004;76:121-5.

[190] Fiotti N, Di Chiara A, Altamura N, Miccio M, Fioretti P, Guarnieri G, et al. Coagulation indicator in chronic stable effort angina and unstable angina: relationship with acute phase reactants and clinical outcome. Blood Coagulation \& Fibrinolysis 2002;13(3):247-55.

[191] Kruskal JB, Commerford PJ, Franks JJ, Kirsch RE. Fibrin and fibrinogen-related antigens in patients with stable and unstable coronary artery disease. The New England Journal of Medicine 1987;317(22):1361-5.

[192] Watanabe R, Wada H, Sakakura M, Mori Y, Nakasaki T, Okugawa Y, et al. Plasma levels of activated protein C-protein $\mathrm{C}$ inhibitor complex in patients with hypercoagulable states. American Journal of Haematology 2000;65:35-40.

[193] Kamikura Y, Wada H, Yamada A, Shimura M, Hiyoyama K, Shiku H, et al. Increased tissue factor pathway inhibitor in patients with acute myocardial infarction. American Journal of Haematology 1997;55:183-7.

[194] Oldgren J, Linder R, Grip L, Siegbahn A, Wallentin L. Coagulation Activity and Clinical Outcome in Unstable Coronary Artery Disease. Arteriosclerosis, Thrombosis, and Vascular Biology 2001;21(6):1059-64.

[195] Tello-Montoliu A, Marin F, Roldan V, Mainar L, Lopez MT, Sogorb F, et al. A multimarker risk stratification approach to non-ST elevation acute coronary syndrome: implications of troponin T, CRP, NT pro-BNP and fibrin D-dimer levels. Journal of Internal Medicine 2007;262(6):651-8.

[196] Bayes-Genis A, Mateo J, Santalo M, Oliver A, Guindo J, Badimon L, et al. D-dimer is an early diagnostic marker of coronary ischemia in patients with chest pain. American Heart Journal 2000;140:379-84. 
[197] Derhaschnig U, Laggner AN, Roggla M, Hirschl MM, Kapiotis S, Marsik C, et al. Evaluation of coagulation markers for early diagnosis of acute coronary syndromes in the Emergency Room. Clinical Chemistry 2002;48(11):1924-30.

[198] Noal MR, Vargas LCR, Halla J, Da Rocha Silla LM. Lack of association between cardiac troponin $\mathrm{T}$ and D-dimer in the evaluation of myocardial damage. Journal of Clinical Laboratory Analysis 2005;19(6):282-4.

[199] Lippi G, Filippozzi L, Montagnana M, Salvagno GL, Guidi GC. Diagnostic value of Ddimer measurement in patients referred to the emergency department with suspected myocardial ischemia. Journal of Thrombosis \& Thrombolysis 2008;25(3):247-50.

[200] Hall C. Essential biochemistry and physiology of (NT-pro) BNP. European Journal of Heart Failure 2004;6:257-60.

[201] Maisel AS, Krishnaswamy P, Nowak RM, McCord J, Hollander JE, Duc P, et al. Rapid measurement of B-type natriuretic peptide in the emergency diagnosis of heart failure. New England Journal of Medicine 2002;347:161-7.

[202] Morrison LK, Harrison A, Krishnaswamy P, Kazanegra R, Clopton P, Maisel A. Utility of a rapid B-natriuretic peptide assay in differentiating congestive heart failure from lung disease in patients presenting with dyspnea. Journal of the American College of Cardiology 2002;39(2):202-9.

[203] Omland T, Aakvaag A, Bonarjee WS, Caidahl K, Lie RT, Nilsen DWT, et al. Plasma brain natriuretic peptide as an indicator of left ventricular systolic function and long-term survival after acute myocardial infarction. Circulation 1996;93:1963-9.

[204] Ruck A, Gustaffson T, Norrborn J, Nowak J, Kallner G, Soderberg M, et al. ANP and BNP but not VEGF are regionally overexpressed in ischemic human myocardium. Biochemical and Biophysical Research Communications 2004;322:287-91.

[205] Goetze JP, Gore A, Moller CH, Steinbruchel DA, Rehfeld JF, Nielsen LB. Acute myocardial hypoxia increases BNP gene expression. FASEB Journal 2004;18(15):1928-30.

[206] Marumoto K, Hamada M, Hiwada K. Increased secretion of atrial and brain natriuretic peptides during acute myocardial ischaemia induced by dynamic exercise in patients with angina pectoris. Clinical Science 1995;88:551-6.

[207] Staub D, Nusbaumer C, Zellweger MJ, Jonas N, Wild D, Pfisterer ME, et al. Use of Btype natriuretic peptide in the detection of myocardial ischemia. American Heart Journal 2006;151(6):1223-30.

[208] Sinclair H, Paterson M, Walker S, Beckett G, Fox KA. Predicting outcome in patients with acute coronary syndrome: evaluation of B-type natriuretic peptide and the global registry of acute coronary events (GRACE) risk score. Scottish Medical Journal 2007;52(3):8-13.

[209] Mega JL, Morrow DA, de Lemos JA, Sabatine SA, Rifai N, Gibson CM, et al. B-type natriuretic peptide at presentation and prognosis in patients with ST-segment elevation myocardial infarction. Journal of the American College of Cardiology 2004;44(2):335-9.

[210] de Lemos JA, Morrow DA, Bentley JH, Omland T, Sabatine MS, McCabe CH, et al. The prognostic value of B-type natriuretic peptide in patients with acute coronary syndromes. New England Journal of Medicine 2001;345:1014-21. 
[211] Morrow DA, de Lemos JA, Sabatine MS, Murphy A, Demopoulous LA, Di Battiste PM, et al. Evaluation of B-type natriuretic peptide for risk assessment in unstable angina/non-ST-elevation myocardial infarction. B-type natriuretic peptide and prognosis in TACTICS-TIMI. Journal of the American College of Cardiology 2003;41(8):1264-72.

[212] Grabowski M, Filipiak KJ, Malek LA, Karpinski G, Huczek Z, Stolarz P, et al. Admission B-type natriuretic peptide assessment improves early risk stratification by Killip classes and TIMI risk score in patients with acute ST elevation myocardial infarction treated with primary angioplasty. International Journal of Cardiology 2007;115(3):386-90.

[213] Ahmed W, Zafar S, Alam AY, Ahktar N, Shah MA, Alpert MA. Plasma levels of B-type natriuretic Peptide in patients with unstable angina pectoris or acute myocardial infarction: prognostic significance and therapeutic implications. Angiology 2007;58(3):269-74.

[214] Sun T, Wang L, Zhang Y. Prognostic Value of B-type Natriuretic Peptide in Patients with Acute Coronary Syndromes. Archives of Medical Research 2006;37(4):502-5.

[215] Kuklinska AM, Sobkowicz B, Kaminski KA, Mroczko B, Musial WJ, Szmitkowski M, et al. The benefits of repeated measurements of B-type natriuretic peptide in patients with first ST-elevation myocardial infarction treated with primary percutaneous coronary intervention. International Heart Journal 2006;47(6):843-54.

[216] Kuklinska AM, Sobkowicz B, Mroczko B, Sawicki R, Musial WJ, Knapp M, et al. Prognostic significance of the admission plasma B-type natriuretic peptide measurement in patients with first ST-elevation myocardial infarction in comparison with C-reactive protein and TIMI risk score. Clinica Chimica Acta 2007;382(1-2):106-11.

[217] Ketch TR, Turner SJ, Sacrinty MT, Lingle KC, Applegate RJ, Kutcher MA, et al. Derived fibrinogen compared with $\mathrm{C}$-reactive protein and brain natriuretic peptide for predicting events after myocardial infarction and coronary stenting. American Heart Journal 2008;156(2):234-40.

[218] Palazzuoli A, Deckers J, Calabro A, Campagna MS, Nuti R, Pastorelli M, et al. Brain natriuretic peptide and other risk markers for outcome assessment in patients with non-ST-elevation coronary syndromes and preserved systolic function. American Journal of Cardiology 2006;98(10):1322-8.

[219] Gunes Y, Okcun B, Kavlak E, Erbas C, Karcier S. Value of brain natriuretic peptide after acute myocardial infarction. Anadolu Kardiyoloji Dergisi 2008;8(3):182-7.

[220] Mukoyama M, Nakao K, Obata K, Jougasaki M, Yoshimura M, Morita E, et al. Augmented secretion of brain natriuretic peptide in acute myocardial infarction. Biochemical and Biophysical Research Communications 1991;180(1):431-6.

[221] Morita E, Hirofumi Y, Michihiro Y, Ogawa H, Jougasaki M, Matsumura T, et al. Myocardial injury/infarction: increased plasma levels of brian natriuretic peptide in patients with acute myocardial infarction. Circulation 1991;88(1):82-91.

[222] Horio T, Shimada KE, Hokno M, Yoshimura T, Kawabayashi T, Yasunari K, et al. Serial changes in atrial and brain natriuretic peptides in patients with acute myocardial infarction treated with early coronary angioplasty. American Heart Journal 1993;126:293-9. 
[223] Kikuta K, Yasue H, Yoshimura M, Morita E, Sumida H, Kato H, et al. Increased plasma levels of B-type natriuretic peptide in patients with unstable angina. American Heart Journal 1996;132:101-7.

[224] Palazzuoli A, Rizzello V, Calabro A, Gallotta M, Martini G, Quatrini I, et al. Osteoprotegerin and B-type natriuretic peptide in non-ST elevation acute coronary syndromes: relation to coronary artery narrowing and plaques number. Clinica Chimica Acta 2008;391(1-2):74-9.

[225] Paelinck BP, Vrints CJ, Bax JJ, Bosmans JM, De Hert SG, de RA, et al. Relation of B-type natriuretic peptide early after acute myocardial infarction to left ventricular diastolic function and extent of myocardial damage determined by magnetic resonance imaging. American Journal of Cardiology 2006;97(8):1146-50.

[226] Brown A, George J, Murphy MJ, Struthers A. Could BNP screening of acute chest pain cases lead to safe earlier discharge of patients with non-cardiac causes? A pilot study. QJM 2007;100(12):755-61.

[227] Bassan R, Potsch A, Maisel A, Tura B, Villacorta H, Nogueira MV, et al. B-type natriuretic peptide: a novel early blood marker of acute myocardial infarction in patients with chest pain and no ST-segment elevation. European Heart Journal 2005;26:234-40.

[228] Hamilton AJ, Swales LA, Neill J, Murphy JC, Darragh KM, Rocke LG, et al. Risk stratification of chest pain patients in the emergency department by a nurse utilizing a point of care protocol. European Journal of Emergency Medicine 2008;15:9-15.

[229] Kwan G, Isakson SR, Beede J, Clopton P, Maisel AS, Fitzgerald RL. Short-term serial sampling of natriuretic peptides in patients presenting with chest pain. Journal of the American College of Cardiology 2007;49(11):1186-92.

[230] Brown AM, Sease KL, Robey JL, Shofer FS, Hollander JE. The impact of B-type natriuretic peptide in addition to troponin I, creatine kinase-MB, and myoglobin on the risk stratification of emergency department chest pain patients with potential acute coronary syndrome. Annals of Emergency Medicine 2007;49(2):153-63.

[231] Glatz JFC, van der Voort D, Hermens WT. Fatty acid-binding protein as the earliest available plasma marker of acute myocardial injury. Journal of Clinical Ligand Assay 2002;25(2):167-77.

[232] Glatz JFC, van Bilsen M, Paulussen RJA, Veerkamp JH, van der Vusse GJ, Reneman RS. Release of fatty acid-binding protein from isolated rat heart subjected to ischemia and reperfusion or to the calcium paradox. Biochimica et Biophysica Acta (BBA) Lipids and Lipid Metabolism 1988;961(1):148-52.

[233] Tanaka T, Hirota Y, Sohmiya K, Nishimura S, Kawamura K. Serum and urinary human heart fatty acid-binding protein in acute myocardial infarction. Clinical Biochemistry 1991;24(2):195-201.

[234] Mad P, Domanovits H, Fazelnia C, Stiassny K, Russmuller G, Cseh A, et al. Human heart-type fatty-acid-binding protein as a point-of-care test in the early diagnosis of acute myocardial infarction. QJM 2007;100(4):203-10.

[235] Alhashemi JA. Diagnostic accuracy of a bedside qualitative immunochromatographic test for acute myocardial infarction. American Journal of Emergency Medicine 2006;24(2):149-55. 
[236] Seino Y, Ogata K, Takano T, Ishii J, Hishida H, Morita H, et al. Use of a whole blood rapid panel test for heart-type fatty acid-binding protein in patients with acute chest pain: comparison with rapid troponin $\mathrm{T}$ and myoglobin tests.[see comment]. American Journal of Medicine 115(3):185-90, 2003 Aug 15.

[237] Ghani F, Wu AH, Graff L, Petry C, Armstrong G, Prigent F, et al. Role of heart-type fatty acid-binding protein in early detection of acute myocardial infarction. Clinical Chemistry 2000;46(5):718-9.

[238] Valle HA, Riesgo LGC, Bel MS, Gonazalo FE, Sanchez MS, Oliva LI. Clinical assessment of heart-type fatty acid-binding protein in early diagnosis of acute coronary syndrome. European Journal of Emergency Medicine 2008;15(3):140-4.

[239] Panju AA, Hemmelgam BR, Guyatt GH, Simei DL. The rational clinical examination: Is this patient having a myocardial infarction. JAMA 1998;280(14):1256-63.

[240] Body R, McDowell G, Carley S, Wibberley C, Gerguson J, Mackway-Jones K. A FABPulous rule out strategy? Heart fatty acid binding protein and troponin for rapid exclusion of acute myocardial infarction. Resuscitation 2011; 82: 1041-6.

[241] Body R, Carley S, McDowell G, Jaffe AS, France M, Cruickshant K, Wibberley C, Nuttall M, Mackway-Jones K. Rapid exclusion of acute myocardial infarction in patients with undetectable troponin using a high sensitivity assay. J Am Coll Cardiol 2011; 58: 1333-9. 


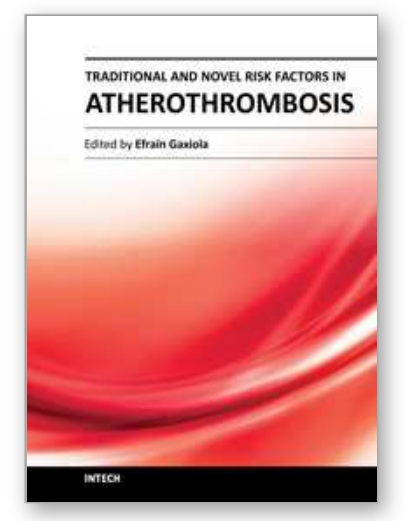

\author{
Traditional and Novel Risk Factors in Atherothrombosis \\ Edited by Dr. Efrain Gaxiola
}

ISBN 978-953-51-0561-9

Hard cover, 140 pages

Publisher InTech

Published online 20, April, 2012

Published in print edition April, 2012

Atherothrombosis has reached pandemic proportions worldwide. It is the underlying condition that results in events leading to myocardial infarction, ischemic stroke and vascular death. As such, it is the leading cause of death worldwide manifested mainly as cardiovascular/cerebrovascular death. The complex and intimate relationship between atherothrombosis and traditional and novel risk factors is discussed in the following chapters of Traditional and Novel Risk Factors in Atherothrombosis - from basic science to clinical and therapeutic concerns. Beginning with pathology and pathophysiology of atherothrombosis, plaque rupture/disruption, this book continues with molecular, biochemical, inflammatory, cellular aspects and finally analyzes several aspects of clinical pharmacology.

\title{
How to reference
}

In order to correctly reference this scholarly work, feel free to copy and paste the following:

Richard Body, Mark Slevin and Garry McDowell (2012). Biomarkers of Atherosclerosis and Acute Coronary Syndromes - A Clinical Perspective, Traditional and Novel Risk Factors in Atherothrombosis, Dr. Efrain Gaxiola (Ed.), ISBN: 978-953-51-0561-9, InTech, Available from: http://www.intechopen.com/books/traditional-andnovel-risk-factors-in-atherothrombosis/biomarkers-of-atherosclerosis

\section{INTECH}

open science | open minds

\section{InTech Europe}

University Campus STeP Ri

Slavka Krautzeka 83/A

51000 Rijeka, Croatia

Phone: +385 (51) 770447

Fax: +385 (51) 686166

www.intechopen.com

\section{InTech China}

Unit 405, Office Block, Hotel Equatorial Shanghai

No.65, Yan An Road (West), Shanghai, 200040, China

中国上海市延安西路65号上海国际贵都大饭店办公楼 405 单元

Phone: +86-21-62489820

Fax: +86-21-62489821 
(C) 2012 The Author(s). Licensee IntechOpen. This is an open access article distributed under the terms of the Creative Commons Attribution 3.0 License, which permits unrestricted use, distribution, and reproduction in any medium, provided the original work is properly cited. 